\title{
LABOR MARKET IMPACTS OF EMPLOYMENT QUOTAS FOR THE DISABLED IN BRAZIL
}

\author{
Alexandre Gori Maia * \\ Vinicius Gaspar Garcia ${ }^{\dagger}$
}

\begin{abstract}
The occupational achievements of people with disabilities and those with less severe functional limitations are analyzed before and after the implementation of employment quotas. The differentials are decomposed into (i) productive or socioeconomic factors; and (ii) unobservable factors such as discrimination and other social constraints. The unobservable difficulties, which play an important role in determining differences in employment rates, reduced substantially, especially for people with more severe limitations. However, while these workers continue to obtain low paid jobs, those most qualified with less severe limitations attained the better occupational positions, and hence, higher wages.
\end{abstract}

Keywords: disability, discrimination, minorities, decomposition method, selectivity bias.

\section{Resumo}

A inserção ocupacional das pessoas com deficiências e com limitações funcionais menos severas são analisados antes e após a implementação da Lei das Cotas. Os diferenciais são decompostos em (i) fatores produtivos ou socioeconômicos; e (ii) fatores não observáveis, como discriminação e dificuldades sociais. Os fatores não observáveis, que desempenham um papel importante na determinação das diferenças nas taxas de emprego, reduziram substancialmente, especialmente para aqueles com limitações mais severas. Entretanto, enquanto esses trabalhadores continuam obtendo empregos de baixa remuneração, os ocupados com limitações menos severas e mais qualificados atingiram as melhores posições ocupacionais e salários mais elevados.

Palavras-chave: deficiência, discriminação, minorias, método de decomposição, viés de seleção.

JEL classification: J14, J31, J48, J71, C52.

DOI: http://dx.doi .org/10.11606/1980-5330/ea141318

\footnotetext{
*Universidade Estadual de Campinas (Unicamp), Brazil. E-mail: gori@unicamp.br

† Faculdades de Campinas (Facamp), Brazil. E-mail: vggarcia30@gmail.com.
} 


\section{Introduction}

People with disabilities are markedly characterized by their low level of socioeconomic attainment and labor participation when compared to other social groups (see Haveman \& Wolfe (1990); Garcia \& Maia (2014); McNeil (2000); Yelin \& Katz (1994)). Among the determinants of these unfavorable conditions are health problems that limit labor productivity and occupational attainment, as well as social prejudice and employers' discrimination (Beegle \& Stock 2003).

Among the recent political achievements of this social group, employment quotas have been adopted in several countries to guarantee a percentage of jobs in public and private companies for persons with disabilities. Supporters of such public policies targeted at people with disabilities advocate that it makes the labor market more inclusive and is able to promote convergence in the distribution of skills between social minorities and majorities (Welch 1976). First, by requiring the employer to adapt the workplace and ensure equality of opportunity in the access to work, reducing segregation between people with and without disabilities (Ravaud et al. 1992). Second, by mitigating the unreasonable effect of social discrimination, promoting greater income equality among workers with similar productivity levels.

On the other hand, critics of this labor protection policy argue that it tends to involve high costs to employers and society, with negative impacts on overall employment generation (Olson 1997). In the case of quotas for people with disabilities, there would also be difficulties to ensure equal treatment for all levels of disability (Hasegawa 2007). For example, people with moderate disabilities could benefit more at the expense of those with more severe levels of disabilities and in more vulnerable conditions.

This study analyzes the differentials of employment rate and average wages in Brazil between 2000 and 2010, a period in which employment quotas for people with disabilities were effectively enforced in Brazil. Analyses are based on pooled sample data from the Brazilian Demographic Census. The paper adopts a classification for people with disabilities which determines more accurately the impacts of employment quotas on a group of people with higher levels of physical, sensorial, or cognitive limitations (severely disabled persons), distinguishing them from a group with milder limitations (mildly disabled persons).

Two strategies are used to evaluate the impacts of employment quotas on the groups of severely disabled, mildly disabled, and nondisabled persons: without and with sample selection correction. Firstly, based on Blinder (1973) and Oaxaca (1973), the study decomposes the impacts of employment quotas on both the labor force participation and on the wage distribution into: i) impact of observable factors (socioeconomic characteristics); ii) impact of unobservable factors (discrimination and social constraints, for example). Results emphasize how the implementation of employment quotas is related to a deep reduction in the differences of employment rates due to unobservable factors and to the reduction in the differences of average wages due to unobservable factors. Secondly, the study controls the presence of sample selection bias in the groups of waged workers using the decomposition method proposed by Neunan and Neuman \& Oaxaca (2004a). Results highlight how the selectivity bias tends to be higher among groups with less severe (or lack of) disabilities and hence, reducing real differences between disabled and nondi- 
sabled waged workers.

The decomposition is applied running separate equations for each group of disability and each year (similar to, for example, Kidd et al. (2000); Madden (2004); Malo \& Pagán (2012)). Differences due to observable and unobservable factors are then compared between the two census years. This empirical strategy has its advantages and limitations. One main advantage is that it allows us to estimate changes in the share of the wage and employment differences attributed to productivity-related and unobservable differences. Since employment quotas are expected to reduce mainly the latter component, which is often interpreted as indicative of discrimination, we can have straightforward evidences of their potential impacts on disabled population. On the other hand, one main limitation is that, unlike other minority groups, persons with disabilities hold health impairments that may severely limit their productivity in some types of work, and these limitations are hardly unraveled by empirical exercises. In contrast to a true experimental (or quasi-experimental) design, the treatment and control groups in this study are independent samples which reasonably differ in their composition in each period. In this regard, the selectivity corrected decomposition proposed by Neunan and Neuman \& Oaxaca (2004a) provides additional information to test the consistency and robustness of the estimates under different hypothesis of what really constitutes labor market inequities.

The study contributes to the growing debate on the impacts of target policies for people with disabilities on the labor market (Acemoglu \& Angrist 1998, Beegle \& Stock 2003, Deleire 2000, Jones 2008). Few studies have tried to analyze the case of employment quotas in Brazil (for example, Costilla et al. (2002)). Particularly, this is the first study to estimate and decompose the potential impacts of employment quotas on wage and employment differences in Brazil, notorious for its high levels of inequality and social exclusion.

The law guaranteeing employment quotas for people with disabilities in Brazil was approved in 1991 (Article 93, Law 8,213 of 1991) and regulated in 1999 by the Federal Decree 3,298 of 1999. But the regulation of the employment quotas began effectively in the year 2000 (Zanitelli 2013). The Ministry of Labor and Employment in Brazil oriented companies with 100 or more employees to hire between $2 \%$ and $5 \%$ of people with disabilities, depending on the company size. Firms had a deadline to adapt to this law, but compliance was almost completely ignored. Fines began to be imposed in 2003 when the law began to be effectively enforced in Brazil. Although employment quotas have positively impacted the occupational attainment and earning distribution of people with disabilities, the final discussion stresses how the persistence of substantial gaps between the groups of disability reinforces the idea that reserving jobs in the market will be unable, per se, to equalize the inequality of opportunities faced by this social group.

\section{Institutional Background}

\subsection{Functional Limitations and Social Prejudice}

By the early twentieth century, people with disabilities had their trajectory defined almost exclusively by their families (Figueira 2009). Gradually, this responsibility was considered a public policy, albeit not exactly as a standard social policy, since this duty was actually transferred to private and charity or- 
ganizations frequently supported by the State (Silva 1987). These institutions expanded their action beyond medical rehabilitation, taking responsibility for the education of people with disabilities.

Only recently have disabled people started to attend school and work environments common to the entire population, as well as public and private services such as bars, restaurants, and cinemas (Garcia 2010). Despite recent improvements, they still face huge inequalities in relation to employment opportunities, occupational attainment, earnings, and social conditions. Even in developed nations, the employment rates of disabled people $(44 \%)$ are only about $60 \%$ of those for the general nondisabled population (71\%) (OECD 2003). This difference is far beyond the potential impact of work-limiting disabilities on labor force participation. According to Webber \& Bjelland (2015), the work-limiting disabilities in the United States tend to reduce the percentage of men and women in the labor force by only 3 and 2 percentage points, respectively.

In this sense, the difficulties faced by people with disabilities cannot be merely attributed to functional limitations, but may also be related to other hidden difficulties such as lack of proper accommodation in the workplace, social prejudice, or discrimination. In the United Kingdom, studies suggest that about half of the differences in employment probabilities is due to unobservable factors such as discrimination and other hidden difficulties faced by people with disabilities (Jones 2008). Nonetheless, this unexplained component may narrow substantially when accounting for selectivity in health or labor force status, i.e., differences in the composition of the disabled and nondisabled working age populations. According to Madden (2004), the selectivity is insignificant for health status, but considerable for the entry into the labor market. Frutos \& Castello (2015) also highlight the role of the system of benefits for people with disabilities, which negatively affected the likelihood of employment among mildly disabled people in Spain.

The average income from work of the disabled population also tends to differ reasonably from that of the nondisabled population. In the United States, for example, the work income of disabled workers is roughly $30 \%$ lower than that of nondisabled workers, and $40 \%$ lower in Portugal (OECD 2003). The lower wages received by people with disabilities can be attributed to several factors. Occupational segregation, for example, limits the earnings potential of people with disabilities. Studies in the United States and in Brazil highlight how people with disabilities are subjected to lower-skilled jobs with limited educational and experience requirements (Maroto \& Pettinicchio 2014, Garcia \& Maia 2014).

Even after controlling for several differences in human capital and occupational characteristics, disabled workers tend to earn significantly less than nondisabled workers (Haveman \& Wolfe 1990, Kidd et al. 2000). As would be expected, the impact of this unexplained wage gap, which is used as evidence of earning discrimination, will largely depend on the quality of the control variables. Different strategies have been used to control for productivity and the level of health disabilities. Deleire (2001), for example, separately analyzed a group of workers with functional limitations but no work limitations, concluding that only a small fraction of their earning gap in relation to nondisabled workers - roughly 5 to 8 percent - can be attributed to discrimination. Jones (2006) and Malo \& Pagán (2012) also controlled for the effect of health on productivity, suggesting that the employment discrimination against the disabled 
is small or even insignificant. In other words, depending on the job requirements, the severity of the disability can reduce significantly an individual's productivity. In this sense, policies should therefore focus on increasing the productivity of the disabled (Jones 2008).

\subsection{Policies for People with Disability}

In order to reduce wage and employment gaps between disabled and nondisabled persons, several policies have been implemented in the labor market. These policies can be classified into three main groups (Hasegawa 2007): i) equality of opportunity, which is oriented to adapt the workplaces and to criminalize discrimination against people with disabilities in hiring, firing, and paying (implemented, for example, in the United States, Australia, United Kingdom, and Canada); ii) employment quotas, which reserve a share of jobs in private and public companies for people with disabilities (implemented, for example, in Germany, France, Italy, Austria, Japan, South Korea, and Brazil); iii) removing difficulties, which forces employers to improve the workplace environment for people with disabilities in accordance with their needs (implemented, for example, in Sweden and Norway).

The Americans with Disabilities Act (ADA) is a well-documented example of an equality of opportunity policy. Prior studies suggested negative or insignificant impacts of this policy on the labor participation rate of people with disabilities. Deleire (2000) analyzed the period of 1986-95 and indicated that the employment of men with disabilities was 7 percentage points lower than before the act was passed. Although the ADA may have increased job accommodation and reduced discrimination against people with disabilities, the costs of complying with the act were large enough to reduce the demand for disabled workers and undo its intended effects. According to Acemoglu \& Angrist (1998), the relative employment position of disabled workers aged 21-39 (and disabled men aged 40-58) began to deteriorate in the first two years the ADA was effectively implemented (1992). This result would be mainly due to the restrictions imposed by employers in order to hire people with disabilities, since they tend to involve increasing costs of hiring and legal risks in case of dismissal. Beegle \& Stock (2003) accounted for the variation in statelevel antidiscrimination measures passed prior to the ADA and suggested that disability discrimination laws were negatively associated with the labor force participation rates of the disabled, but the laws had no relationship with disabled employment rates.

The reduction in the labor participation rate of the disabled population would also be related to the reclassification of many nondisabled and nonparticipants as disabled, stimulated by more stringent requirements of the welfare reform and more generous federal disability benefits (Hotchkiss 2004). Using alternative measures of who is covered by the ADA, Kruse \& Schur (2003) indicated a positive impact on the participation rate of those with any or severe functional limitations who do not report a work disability. The authors also emphasize the pro-cyclic characteristics of labor participation for people with disabilities: they tend to be the last to be hired in periods of growth and the first to be fired in recessions.

The potential benefits of antidiscrimination laws on wages is also controversial. Deleire (2000) and Acemoglu \& Angrist (1998) suggested that the ADA had no impact on wages of disabled workers, although those disabled 
workers who remained employed may have been benefited by the job accommodation imposed by the ADA. In turn, Beegle \& Stock (2003) indicated that state-level antidiscrimination laws had negative impact on earnings, possibly because disabled workers shifted into lower earning jobs or the composition of disabled workers shifted toward disabilities with stronger negative effects on productivity and wages. In the case of employment quotas, growth in the participation rate of people with disabilities would naturally be expected, since a share of the jobs is compulsorily reserved for this group of people. Nonetheless, the intensity of these impacts across different social groups, as in the whole population, is not yet fully understood, neither are the impacts on wage distribution and the employer's discrimination. Some studies suggest that the general impact may be negative. Griffin (1992) modeled affirmative action as a series of hiring quotas and indicated that, once quotas are binding, firms subject to affirmative action will operate under higher costs of production and have less elastic demands for inputs. They will be less able to substitute between most inputs. As a consequence, employment quotas may benefit the target social group of workers, but it also reduces the industry's production and employment of labor (Marchon \& Toledo 2014).

Other studies suggest positive but tiny impacts. In South Korea, changes in the employment quota system that took place in 2003 have shown to increase labor force participation, but have had a limited positive impact on the probability of employment among people with disabilities (Nazarov et al. 2015). A main concern is whether the penalty for non-compliance provides sufficient incentives for firms to hire disabled workers. Wüllrich (2010) investigated the effect of a tax increase of $30 \%$ on firms' demand for disabled workers in Austria, concluding that the average number of disabled employees would increase by $1.9 \%$.

\section{Empirical Framework}

There is a wide variety of physical, sensory and cognitive limitations representing different levels of functional limitations. Brazil currently works with the so-called "social paradigm"of disability, assuming that, beyond physical impairments, the condition of disability is also determined by the social environment, the levels of accessibility and autonomy that people experience in their lives (Sassaki 2008). However, in order to be granted a social benefit such as those guaranteed by the "employment quotas", individuals will only be considered as having a disability if they, based on a medical report, meet the definitions of physical, visual, hearing, mental or multiple disabilities, listed in the Decree-Law 5296/04.

But the assessment of disability according to this criterion is very difficult to obtain in household surveys. As an alternative, the Brazilian Institute of Geography and Statistics (IBGE) uses the International Classification of Functioning, Disability and Health (ICF) to classify people with disabilities based on self-reported answers. In particular, the Brazilian Demographic Census assesses the degree of difficulty (total, great, some or none) to walk/climb stairs, hear and see, in addition to a specific question for mental disability.

However, the challenge is to conciliate these self-reported answers with the official criteria of physical, sensory or mental disability used in the employment quotas. Besides those who declared themselves totally unable to 
walk, see or hear, it would also be appropriate to include individuals who declared "great difficulty" in performing these actions, excluding those who reported only "some difficulty". Thus, the groups of disability or functional limitations are proposed for the analysis:

- Severely disabled: "severely disabled person", those who reported "total"or "great"difficulty in seeing, hearing and/or walking/climbing stairs; in addition to those who declared "yes"to "intellectual/mental disability";

- Mildly disabled: "mildly disabled person", those who reported only "some" difficulty in seeing, hearing and/or walking/climbing stairs.

- Nondisabled: people who did not declare any kind of disability or functional limitation.

Disabled persons (or people with disabilities) will henceforth refer to both severely and mildly disabled groups ${ }^{1}$. The group with more severe disabilities would be the main target of employment quotas, since the severely disabled persons would face more adverse conditions in terms of schooling and job access due to barriers and obstacles that still exist in society. As a consequence, they would present disadvantages in terms of employment, earnings and other socioeconomic conditions in comparison with both the nondisabled population and the group with less severe functional limitations.

Differences between severely disabled, mildly disabled and nondisabled persons were analyzed comparing two indicators: (i) employment-to-population ratio (ER), which is the percentage of the working age population (WAP, people between 15 and 65 years) who is actually employed with a positive remuneration; (ii) wage, monthly income of the main job for those who were employed with a positive remuneration.

\subsection{Equation Models}

The models for the occupational employment and wage of the $i$-th individual are given by:

$$
\begin{aligned}
& E_{g t_{i}}=\mathbf{h}_{g t_{i}}^{\prime} \gamma_{g t}+\epsilon_{g t_{i}} \\
& Y_{g t_{i}}=\mathbf{x}_{g t_{i}}^{\prime} \beta_{g t}+u_{g t_{i}}
\end{aligned}
$$

These equations are adjusted separately for each group of disability $g$ ( $g=$ $S$ for severely disabled, $M$ for mildly disabled and $N$ for nondisabled person) and period $t$ ( $t=0$ for 2000 and 1 for 2010).

In the wage equation, the dependent variable $Y$ represents the natural logarithm of the monthly wage (log wage) for the employed population with positive earnings. Wages are represented by monthly payments rather than hourly payments because most employment contracts in Brazil consider a fixed compensation per month (for example, Hoffmann (2000)). Wages of 2000

\footnotetext{
${ }^{1}$ The disability rights movement in Brazil prefers the words "people with disability", although the term "disabled person"is worldly recognized and almost always considered correct.
} 
were converted to constant values of July 2010 using the Índice Nacional de Preços ao Consumidor, provided by the IBGE ${ }^{2}$.

In the equation for ER of the WAP, the binary dependent variable $E$ assumes 0 , for non-employed, and 1, for employed persons. In other words, the Equation 1 represents a Linear Probability Model (LPM) for the probability of being employed. The LPM is a simple and usually convenient approximation to the underlying response probability, especially when one is only interested in analyzing the average net impacts of the explanatory variables for the middle ranges of the data (Wooldridge 2002).

The vectors $\mathbf{h}$ and $\mathbf{x}$ contain the values for the observable explanatory variables respectively for the employment and wage equations; the vectors $\gamma$ and $\beta$ contain the coefficients that reflect the net impact of each explanatory variable; $\epsilon$ and $u$ are the random errors.

Since wages $Y$ are only observed for those employed persons $(E>0)$, a standard assumption is that errors $u$ in the wage equation are not correlated with errors in the equation for ER. Otherwise, the estimation of the wage equation will suffer from sample selection problems and the Ordinary Least Squares' estimators will not be consistent (Wooldridge 2002). This is the case when the group of employed individuals is not merely a random selected sample of the WAP, and unobserved factors that affect labor force participation (motivation and discrimination, for example) will also affect wages.

The second approach to estimate the differences between the groups of disability uses the Heckit method to obtain consistent estimators of the wage equation in the presence of sample selectivity (Heckman 1976). The wage equation with sample selection correction can be expressed as:

$$
Y_{g t_{i}}=\mathbf{x}_{g t_{i}}^{\prime} \beta_{g t}+\theta_{g t} \lambda_{g t_{i}}+u_{g t_{i}}
$$

Where the parameter $\theta$ represents the product between $\rho$ (the correlation between errors $u$ and $\epsilon$ ) and $\sigma$ (the standard error of $u$ ), and the variable $\lambda$ contains the values of the Inverse Mills Ratio (IMR). This means that the selectivity bias will occur when $\theta \neq 0$.

As pointed by Wooldridge (2002), $\mathbf{x}$ does not need to be a strict subset of $\mathbf{h}$ for $\beta$ to be identified. Exogenous instruments - those correlated to the probability of employment and exogenous to individual wages - can be used in the first stage of estimation (Equation 1) in order to reduce collinearity and minimize the standard errors in the second stage of estimation (Equation $3)$. In turn, the estimates obtained in the second stage will not be consistent when endogenous instruments are used in the first stage. We tested several instruments recommended by previous studies (for example, (Neuman \& Oaxaca 2004b, Baldwin \& Choe 2014, Frutos \& Castello 2015)), but all of them showed to be significantly related to errors in Equation 3. In this sense, our vector $\mathbf{h}$ contains only explanatory variables presented in vectors $\mathbf{x}$. Although this strategy tends to generate collinearity in the second stage, this is not a problem in large data sets. The estimates are consistent and the large number of degrees of freedom in the Demographic Census guarantees their desired significance.

\footnotetext{
${ }^{2}$ Conversion to constant values of 2010 was made using the deflator 1.952 , which means an inflation of $95.2 \%$ between July 2000 and July 2010 .
} 
The vector $\mathbf{h}$ includes binary variables for education, age, sex, and race/color. The vector $\mathbf{x}$ contains, in addition to those variables presented in vector $\mathbf{h}$, binary variables for working hour, employment status, and economic sector. The list and description of the explanatory variables is presented in Appendix A. In addition to social and occupational variables, both models include fixed effects for the 27 federal units in Brazil.

\subsection{Decomposition Method}

The effect of employment quotas on the outcome variable ( $E$ for ER or $Y$ for log wage) can be derived from the total differences between a treatment group, which is affected by the policy change, and a control group, which is not affected, in two consecutive periods, before $(t=0)$ and after the implementation of the employment quotas $(t=1)$. For example, the total differences between the average wages of severely disabled ( $g=S$, treatment group) and nondisabled ( $g=N$, control group) workers is given by:

$$
\Delta \bar{Y}_{S N}=\left(\bar{Y}_{S 1}-\bar{Y}_{N 1}\right)-\left(\bar{Y}_{S 0}-\bar{Y}_{N 0}\right)=\Delta \bar{Y}_{1}-\Delta \bar{Y}_{0}
$$

Where $\bar{Y}_{S 0}$ and $\bar{Y}_{N 0}$ are, respectively, the average wages for the groups of severely disabled and nondisabled workers before the intervention $(t=0)$; $\bar{Y}_{S 1}$ and $\bar{Y}_{C 1}$ are the average wages after the intervention $(t=1)$.

Since data in this study arise from a natural experiment where the treatment and control groups differ systematically over the two periods, it is very difficult to infer a causal connection between the policy (employment quotas) and the outcome of interest. In other words, other factors may impact the total difference between the mean outcomes (Equation 4) besides the policy under analysis. The literature on treatment evaluation provides a rich variety of methods to be applied in different contexts (Cameron \& Trivedi 2005). In order to obtain an unbiased estimate of the total impacts, the main idea is to control for both observable or unobservable factors that can be related to both the outcome of interest and the policy intervention.

In this regard, differences between the treatment and control groups in each period will be decomposed into: (i) differences due to observable characteristics group (obs) such as education and working experience; or (ii) differences due to unobservable characteristics (unobs) such as physical barriers to access a job or social discrimination.

$$
\Delta \bar{Y}=\left(o b s_{1}-o b s_{0}\right)+\left(u n o b s_{1}-u n o b s_{0}\right)
$$

Equation 5 indicates that the difference between the treatment and control groups can be represented by changes in the observable $\left(o b s_{1}-o b s_{0}\right)$ and in the unobservable $\left(u_{n o b s}-u n o b s_{0}\right)$ characteristics. Changes due to observable characteristics represent changes in socioeconomic characteristics that are not directly affected by employment quotas, such as access to education and age structure. In turn, changes due to unobservable characteristics are thought to be mainly related to the net effect of employment quotas, since it represents, among other factors, changes in adverse and hidden conditions faced by disabled persons due to their infrastructure constraints and/or social barriers. 
The decomposition method adopted in this study considered two strategies of estimation: without and with sample selection correction. The first strategy is based on the method proposed by Blinder (1973) and Oaxaca (1973) and assumes that the groups of severely disabled, mildly disabled, and nondisabled workers are random samples of their respective populations. The second strategy uses the method proposed by Neuman \& Oaxaca (2004a) and assumes that the groups of workers differ in unobserved factors that are also related to the wage determination. Both methods use Equations 1 and 2 to decompose the difference between the mean outcome for the treatment and control groups in each period $t$. Three combinations of treatment and control groups are compared: (i) severely disabled $(g=S)$ and mildly disabled persons $(g=M)$; (ii) severely disabled $(g=S)$ and nondisabled persons $(g=N)$; (iii) mildly disabled $(g=M)$ and nondisabled $(g=N)$ persons.

\section{Without Sample Selection Correction}

The first step is to represent the average outcome as a function of the observed variables and the coefficients. For example, the equation for the average wage for the group of disability $g$ in period $t$ is given by:

$$
\bar{Y}_{g t}=\overline{\boldsymbol{x}}_{g t}^{\prime} \widehat{\boldsymbol{\beta}}_{g t}
$$

Where $\widehat{\beta}$ is the ordinary least squares (OLS) estimate for the vector of coefficients $\beta$.

Making some algebraic developments, the difference between, for example, the averages wages of severely disabled and nondisabled workers in period $t$ can be represented by (Blinder 1973, Oaxaca 1973) ${ }^{3}$ :

$$
\left(\bar{Y}_{S t}-\bar{Y}_{N t}\right)=\left(\bar{x}_{S t}^{\prime}-\bar{x}_{N t}^{\prime}\right) \widehat{\beta}_{N t}+\bar{x}_{S t}^{\prime}\left(\widehat{\beta}_{S t}-\widehat{\beta}_{N t}\right)
$$

The first component in Equation 7, also called effect of observable characteristics (obs), represents the value that can be attributed to observable socioeconomic differences between the treatment and the control groups. The second component represents the value that can be attributed to differences in the marginal returns of socioeconomic characteristics between the groups. This term, also called effect of coefficients or unobservable factors (unobs), represents the difference between the average values of $Y$ that cannot be merely explained by differences in socioeconomic characteristics.

Merging Equations 4 and 7, the variation in the difference between the average wages of severely disabled and nondisabled workers will be given by:

$$
\begin{aligned}
\left(\bar{Y}_{S t}-\bar{Y}_{N t}\right)= & {\left[\left(\overline{\boldsymbol{x}}_{S 1}^{\prime}-\overline{\boldsymbol{x}}_{N 1}^{\prime}\right) \widehat{\boldsymbol{\beta}}_{N 1}-\left(\overline{\boldsymbol{x}}_{S 0}^{\prime}-\overline{\boldsymbol{x}}_{N 0}^{\prime}\right) \widehat{\boldsymbol{\beta}}_{N 0}\right]+} \\
& {\left[\overline{\boldsymbol{x}}_{S 1}^{\prime}\left(\widehat{\boldsymbol{\beta}}_{S 1}-\widehat{\boldsymbol{\beta}}_{N 1}\right)-\overline{\boldsymbol{x}}_{S 0}^{\prime}\left(\widehat{\boldsymbol{\beta}}_{S 0}-\widehat{\boldsymbol{\beta}}_{N 0}\right)\right] }
\end{aligned}
$$

\footnotetext{
${ }^{3}$ Alternatively, we could also decompose the difference between the average wages by $\left(\bar{x}_{S t}^{\prime}-\bar{x}_{N t}^{\prime}\right) \widehat{\beta}_{S t}+\bar{x}_{N t}^{\prime}\left(\widehat{\beta}_{S t}-\widehat{\beta}_{N t}\right)$ (Vaz \& Hoffmann 2007). We tested both approaches, finding no remarkable differences between the analyses. For analytical simplicity, we opted for Equation 7.
} 
In other words, differences between the treatment and the control groups can increase or decrease due to changes in observable socioeconomic characteristics ( $\Delta o b s$, which is the first term between square brackets) or due to changes in unobservable characteristics ( $\Delta$ unobs, which is the second term between square brackets), which is the main concern in the evaluation of the employment quotas.

We used similar procedures to decompose changes in the differences between employment rates of treatment and control groups. In this case, the variation in the differences between the mean outcomes is represented by $\Delta \bar{E}$, the vector of average values for the explanatory variables is $\overline{\boldsymbol{h}}$ and the vector of OLS estimates is $\widehat{\gamma}$. These procedures were used to compare the treatment and control groups (subscript $g$ ): (i) severely disabled $(S)$ and mildly disabled persons $(M)$; (ii) severely disabled $(S)$ and nondisabled persons $(N)$; (iii) mildly disabled $(M)$ and nondisabled $(N)$ persons.

\section{With sample selection correction}

A main limitation of the previous decomposition approach is that it does not account for sample selection bias in the wage equation, i.e., differences in the composition of disabled and nondisabled employed populations due to unobservable factors that are also correlated to wage. The second strategy of this study uses the method proposed by Neuman \& Oaxaca (2004a) to decompose wage differences between the groups of disability accounting for sample selectivity.

The first step is to represent the average wage as a function of the estimates for the sample selection correction parameters. Merging Equations 3 and 6, we have:

$$
\bar{Y}_{g t}=\overline{\boldsymbol{x}}_{g t}^{\prime} \widehat{\boldsymbol{\beta}}_{g t}+\theta_{g t} \lambda_{g t}
$$

Where $\hat{\theta}$ is the maximum likelihood (ML) estimate for $\rho \bar{\lambda}_{u}$ is the average value of the IMR, obtained in the first step of estimation (Equation 1). Now, merging Equations 9 and 7 we have a new expression for the difference between the average wages of the severely disabled and nondisabled workers in time $t$ (Neuman \& Oaxaca 2004a):

$$
\left(\bar{Y}_{S t}-\bar{Y}_{N t}\right)=\left(\overline{\boldsymbol{x}}_{S t}^{\prime}-\bar{x}_{N t}^{\prime}\right) \beta_{N t}+\bar{x}_{S t}^{\prime}\left(\widehat{\boldsymbol{\beta}}_{S t}-\widehat{\boldsymbol{\beta}}_{N t}\right)+\left(\widehat{\theta}_{S t} \lambda_{S t}-\widehat{\theta}_{N t} \bar{\lambda}_{N t}\right)
$$

Where the last component in Equation 10 represents the role of selectivity on overall wage differences between treatment and control groups. As a result, the variation in the differences between the treatment and control groups before $(t=0)$ and after $(t=1)$ the policy implementation will now contain a component that is due to selectivity bias:

$$
\begin{aligned}
\left(\bar{Y}_{S t}-\bar{Y}_{N t}\right)= & {\left[\left(\overline{\boldsymbol{x}}_{S 1}^{\prime}-\overline{\boldsymbol{x}}_{N 1}^{\prime}\right) \beta_{N 1}-\left(\overline{\boldsymbol{x}}_{S 0}^{\prime}-\overline{\boldsymbol{x}}_{N 0}^{\prime}\right) \beta_{N 0}\right]+} \\
& {\left[\overline{\boldsymbol{x}}_{S 1}^{\prime}\left(\widehat{\beta}_{S 1}-\widehat{\boldsymbol{\beta}}_{N 1}\right)-\overline{\boldsymbol{x}}_{S 0}^{\prime}\left(\widehat{\boldsymbol{\beta}}_{S 0}-\widehat{\boldsymbol{\beta}}_{N 0}\right)\right]+} \\
& {\left[\left(\widehat{\theta}_{S 1} \bar{\lambda}_{S 1}-\widehat{\theta}_{N 1} \bar{\lambda}_{N 1}\right)-\left(\widehat{\theta}_{S 0} \bar{\lambda}_{S 0}-\widehat{\theta}_{N 0} \bar{\lambda}_{N 0}\right)\right] }
\end{aligned}
$$


Or, in summary:

$$
\Delta Y=\Delta o b s+\Delta u n o b s+\Delta s e l e c t i v i t y
$$

Similar to the strategy without sample selection correction, the decomposition proposed by Equation 12 was used to represent the differences between three combinations of treatment and control groups: (i) severely disabled $(S)$ and mildly disabled persons $(M)$; (ii) severely disabled $(S)$ and nondisabled persons $(N)$; (iii) mildly disabled $(M)$ and nondisabled $(N)$ persons.

\section{Results}

\subsection{Data Description}

According to the 2010 Demographic Census, the number of severely disabled persons of working age (15 to 65 ) was 8.2 million (6.2\% of the WAP), while the number of mildly disabled was 25.1 million (19.0\%) (Table 1 ). Therefore, 33.3 million people declared they had at least some degree of permanent sensory, motor and/or cognitive difficulty in 2010. The share of the WAP reporting any type of disability also increased substantially throughout the decade: from $15.5 \%(3.9 \%+11.6 \%)$ in 2000 to $25.2 \%(6.2 \%+19.0 \%)$ in 2010 . Since the classification of disability is based on self-reported answers, two phenomena may be considered in this dynamic: i) the higher prevalence of disabilities in the population, for example, due to an aging population; and ii) the higher recognition or acceptance of this condition, for example, due to better access to health assessments or even a strategy in order to be eligible for social benefits such as employment quotas.

The most representative type of disability is visual impairment, understood as total inability to see $(307,000$ people) and great difficulty (4.1 million), accounting for a total of 4.4 million people in 2010 (3.3\% of the WAP). Next, people with physical disabilities are constituted by 306,000 persons with total inability and 1.9 million with great difficulty to walk/climb stairs, accounting for 2.2 million persons (1.7\% of the WAP). People with mental or cognitive disability represented $1.4 \%$ of the WAP (1.8 million people). In turn, people with hearing impairment represented $0.9 \%$ of the total Brazilian WAP in 2010: 236,000 with total difficulty and 886,000 with great permanent difficulty in hearing (1.1 million people $)^{4}$.

The percentage of the WAP that is effectively employed (ER) is significantly lower for severely disabled compared to mildly disabled and nondisabled persons: $39.5 \%$ in 2010 as opposed to $56.6 \%$ and $62.0 \%$, respectively. Among the severely and mildly disabled persons, the ER is higher for those with hearing impairment, especially for those with visual disabilities (between $43.8 \%$ and $55.5 \%$ ). Among those with mental disabilities, total or great physical difficulty, the ER is very low: between $17.3 \%$ and $31.8 \%$.

Between 2000 and 2010, the ER increased significantly for most groups, especially for those with more severe levels of disabilities. For example, the ER increased by 11 percentage points for the severely disabled persons and by 7

\footnotetext{
${ }^{4}$ It is important to note that the sum of each disability type exceeds the total observed for the disable population ( 8.2 million). This is because the same individual may have declared more than one type of impairment or disability (the so called multiple disabilities).
} 
Table 1: Percentage distribution of socioeconomic characteristics

\begin{tabular}{|c|c|c|c|c|c|c|c|c|c|}
\hline \multirow{3}{*}{$\begin{array}{l}\text { Type of } \\
\text { Disabil- } \\
\text { ity }\end{array}$} & \multirow{3}{*}{ Category } & \multicolumn{4}{|c|}{2000} & \multicolumn{4}{|c|}{2010} \\
\hline & & \multirow{2}{*}{$\begin{array}{c}\text { Sample Size } \\
(1000)\end{array}$} & \multicolumn{2}{|l|}{ People } & \multirow{2}{*}{ ER } & \multirow{2}{*}{$\begin{array}{c}\text { Sample Size } \\
(1000)\end{array}$} & \multicolumn{2}{|l|}{ People } & \multirow{2}{*}{ ER } \\
\hline & & & $N(1,000)$ & $\%$ & & & $N(1,000)$ & $\%$ & \\
\hline \multirow{3}{*}{$\begin{array}{l}\text { Mental } \\
\text { Illness }\end{array}$} & Yes & 232,103 & $1,950,303$ & 1.8 & 21.3 & 208,068 & $1,830,578$ & 1.4 & 17.3 \\
\hline & No & $12,732,059$ & $108,187,813$ & 97.9 & 54.1 & $13,827,541$ & $130,001,363$ & 98.6 & 60.1 \\
\hline & ND & 37,268 & 324,400 & 0.3 & 42.2 & 2,954 & 35,996 & 0.0 & 1.3 \\
\hline \multirow{5}{*}{$\begin{array}{l}\text { Ability } \\
\text { to See }\end{array}$} & Unable & 6,813 & 56,932 & 0.1 & 5.6 & 28,352 & 307,151 & 0.2 & 47.4 \\
\hline & Great Difficulty & 181,537 & $1,498,320$ & 1.4 & 36.4 & 450,617 & $4,076,119$ & 3.1 & 47.2 \\
\hline & Some Difficulty & $1,270,894$ & $10,524,970$ & 9.5 & 47.6 & $2,362,896$ & $22,440,758$ & 17.0 & 55.5 \\
\hline & No Difficulty & $11,504,341$ & $98,050,650$ & 88.8 & 54.4 & $11,191,903$ & $104,985,860$ & 79.6 & 60.9 \\
\hline & $\mathrm{ND}$ & 37,845 & 331,644 & 0.3 & 44.0 & 4,795 & 58,048 & 0.0 & 36.7 \\
\hline \multirow{5}{*}{$\begin{array}{l}\text { Ability } \\
\text { to Hear }\end{array}$} & Unable & 12,469 & 100,642 & 0.1 & 19.2 & 24,203 & 235,656 & 0.2 & 43.8 \\
\hline & Great Difficulty & 49,018 & 405,558 & 0.4 & 35.4 & 99,614 & 886,357 & 0.7 & 47.1 \\
\hline & Some Difficulty & 336,613 & $2,837,207$ & 2.6 & 47.1 & 493,654 & $4,551,103$ & 3.5 & 52.3 \\
\hline & No Difficulty & $12,559,353$ & $106,733,833$ & 96.6 & 53.8 & $13,417,940$ & $126,156,019$ & 95.7 & 59.9 \\
\hline & ND & 43,977 & 385,276 & 0.3 & 45.2 & 3,152 & 38,802 & 0.0 & 5.5 \\
\hline \multirow{5}{*}{$\begin{array}{l}\text { Ability } \\
\text { to Walk }\end{array}$} & Unable & 23,830 & 203,203 & 0.2 & 6.5 & 31,856 & 306,062 & 0.2 & 23.9 \\
\hline & Great Difficulty & 108,066 & 919,517 & 0.8 & 21.7 & 215,301 & $1,929,434$ & 1.5 & 31.8 \\
\hline & Some Difficulty & 417,604 & $3,538,342$ & 3.2 & 36.9 & 594,056 & $5,462,979$ & 4.1 & 42.5 \\
\hline & No Difficulty & $12,419,699$ & $105,520,188$ & 95.5 & 54.4 & $13,193,914$ & $124,127,635$ & 94.1 & 60.8 \\
\hline & ND & 32,231 & 281,266 & 0.3 & 41.2 & 3,436 & 41,827 & 0.0 & 12.1 \\
\hline \multirow{4}{*}{$\begin{array}{l}\text { Group of } \\
\text { Disability }\end{array}$} & Severely Disabled & 520,597 & $4,355,927$ & 3.9 & 28.3 & 904,451 & $8,175,917$ & 6.2 & 39.5 \\
\hline & Mildly Disabled & $1,534,326$ & $12,802,713$ & 11.6 & 49.2 & $2,644,458$ & $25,084,377$ & 19.0 & 56.6 \\
\hline & Nondisabled & $10,858,260$ & $92,536,367$ & 83.8 & 55.3 & $10,484,968$ & $98,551,430$ & 74.7 & 62.0 \\
\hline & ND & 88,247 & 767,509 & 0.7 & 49.9 & 4,686 & 56,212 & 0.0 & 34.2 \\
\hline
\end{tabular}

Source: Demographic Census, IBGE.

Working age population: 10 to 65 years. Average values in column \% for all nominal variables. Standard errors between parentheses. 
percentage points for the mildly disabled and nondisabled. Among the types of disabilities, the ER increased mostly for those with total or great difficulty in seeing and hearing: from 11 to 42 percentage points. In turn, the labor force participation for people with mental problems was even more restricted in 2010 in comparison with 2000, falling by 4 percentage points.

The low levels of labor force participation for people with disabilities can be explained by physical and social constraints such as difficulties accessing the workplace and employers' discrimination, as well as by their socioeconomic characteristics. The groups of mildly and, above all, severely disabled persons are characterized by the relative prevalence of more vulnerable socioeconomic groups (Table 2). For example, in 2010, the percentage of severely disabled WAP with no education $(16.2 \%)$ was more than twice as high as that observed for the mildly disabled $(7.1 \%)$ and more than four times higher than that of nondisabled WAP $(3.7 \%)$. On the other hand, the percentage of disabled WAP with college education $(6.8 \%)$ was almost twice as low as that of mildly disabled $(13.0 \%)$ and nondisabled (17.3\%).

Unsurprisingly, there is a greater relative prevalence of the elderly among disabled persons, especially those between 60 and 65 years old. There is also a greater prevalence of blacks and women among disabled persons. Black and brown people made up more than half of the severely and mildly disabled WAP (54.7\% and 52.9\%, respectively), while they represented $49.9 \%$ among nondisabled in 2010 . Women were $54.6 \%$ and $57.2 \%$ among severely disabled and mildly disabled WAP, respectively, against $49.3 \%$ among the nondisabled.

The most significant socioeconomic changes observed between 2000 and 2010 are related to age distribution, and more specifically the educational attainments of the groups of disability. For example, the share of people 40 years or older increased in all groups, but particularly among severely disabled persons: 7.2 percentage points, as opposed to only 0.6 percentage points among the mildly disabled and 1.3 among the nondisabled. This result would reflect, for example, a higher life expectancy for people with more severe health problems or a higher participation of people with disability in the labor market. In turn, educational attainment increased faster among the mildly disabled and nondisabled. For example, the percentage of the WAP with middle school or college (with or without diploma) increased by more than 16 percentage points among the nondisabled and mildly disabled, and by 11.9 percentage points among severely disabled persons. These results may indicate the persistence of difficulties in accessing and adapting the education system for the severely disabled population.

In addition to lower employment rates, severely disabled persons who are effectively employed also present more vulnerable occupational characteristics than those of the mildly disabled and nondisabled. The average wage of severely disabled workers, for example, was $21 \%$ lower than that of the mildly disabled and 26\% lower than that of the nondisabled in 2010 (Table 3 ). Among other factors, the lower wages of disabled workers reflect the high rates of underemployment in this group. For example, the percentage of workers with partial working hours (less than 40 hours per week) is higher among mildly disabled (26.3\% in 2010$)$, and especially among severely disabled workers $(29.0 \%$ vs. $21.6 \%$ of nondisabled).

Disabled workers are also associated with informal activities and self-employment. For example, the percentage of formal employees among the severely disabled persons was just $40 \%$, as opposed to $43.6 \%$ for the mildly disabled and $51.2 \%$ 
Table 2: Percentage distribution of socioeconomic characteristics

\begin{tabular}{|c|c|c|c|c|c|c|}
\hline \multirow{2}{*}{$\begin{array}{l}\text { Socio- } \\
\text { economic } \\
\text { Characte- } \\
\text { ristics }\end{array}$} & \multicolumn{3}{|c|}{2000} & \multicolumn{3}{|c|}{2010} \\
\hline & $\begin{array}{l}\text { Severely } \\
\text { Disabled }\end{array}$ & $\begin{array}{c}\text { Mildly } \\
\text { Disabled }\end{array}$ & $\begin{array}{c}\text { Non- } \\
\text { disabled }\end{array}$ & $\begin{array}{l}\text { Severely } \\
\text { Disabled }\end{array}$ & $\begin{array}{c}\text { Mildly } \\
\text { Disabled }\end{array}$ & $\begin{array}{c}\text { Non- } \\
\text { disabled }\end{array}$ \\
\hline Sample Size & 520,597 & $1,534,326$ & $10,858,260$ & 904,451 & $2,644,458$ & $10,484,968$ \\
\hline No Education & $\begin{array}{c}29.3 \\
(0.063)\end{array}$ & $\begin{array}{c}15.6 \\
(0.029)\end{array}$ & $\begin{array}{c}6.7 \\
(0.008)\end{array}$ & $\begin{array}{c}16.2 \\
(0.039)\end{array}$ & $\begin{array}{c}7.1 \\
(0.016)\end{array}$ & $\begin{array}{c}3.7 \\
(0.006)\end{array}$ \\
\hline Elementary & $\begin{array}{c}57.5 \\
(0.069) \\
\end{array}$ & $\begin{array}{c}62.8 \\
(0.039) \\
\end{array}$ & $\begin{array}{c}56.0 \\
(0.015)\end{array}$ & $\begin{array}{c}58.8 \\
(0.052)\end{array}$ & $\begin{array}{c}53.5 \\
(0.031) \\
\end{array}$ & $\begin{array}{c}42.5 \\
(0.015)\end{array}$ \\
\hline Middle & $\begin{array}{c}10.2 \\
(0.042)\end{array}$ & $\begin{array}{c}16.1 \\
(0.030)\end{array}$ & $\begin{array}{c}27.4 \\
(0.014)\end{array}$ & $\begin{array}{c}18.3 \\
(0.041)\end{array}$ & $\begin{array}{c}26.4 \\
(0.027)\end{array}$ & $\begin{array}{c}36.5 \\
(0.015)\end{array}$ \\
\hline College & $\begin{array}{c}3.0 \\
(0.024) \\
\end{array}$ & $\begin{array}{c}5.5 \\
(0.018) \\
\end{array}$ & $\begin{array}{c}9.9 \\
(0.009) \\
\end{array}$ & $\begin{array}{c}6.8 \\
(0.027) \\
\end{array}$ & $\begin{array}{c}13.0 \\
(0.021) \\
\end{array}$ & $\begin{array}{c}17.3 \\
(0.012) \\
\end{array}$ \\
\hline 15 to 19 & $\begin{array}{c}8.1 \\
(0.038)\end{array}$ & $\begin{array}{c}6.2 \\
(0.019)\end{array}$ & $\begin{array}{c}18.0 \\
(0.012)\end{array}$ & $\begin{array}{c}5.8 \\
(0.025)\end{array}$ & $\begin{array}{c}6.1 \\
(0.015)\end{array}$ & $\begin{array}{c}15.2 \\
(0.011)\end{array}$ \\
\hline 20 to 29 & $\begin{array}{c}15.9 \\
(0.051) \\
\end{array}$ & $\begin{array}{c}13.2 \\
(0.027) \\
\end{array}$ & $\begin{array}{c}29.6 \\
(0.014) \\
\end{array}$ & $\begin{array}{c}13.2 \\
(0.036) \\
\end{array}$ & $\begin{array}{c}14.0 \\
(0.021) \\
\end{array}$ & $\begin{array}{c}30.2 \\
(0.014) \\
\end{array}$ \\
\hline 30 to 39 & $\begin{array}{c}17.3 \\
(0.052)\end{array}$ & $\begin{array}{c}16.6 \\
(0.030)\end{array}$ & $\begin{array}{c}24.0 \\
(0.013)\end{array}$ & $\begin{array}{c}15.1 \\
(0.038)\end{array}$ & $\begin{array}{c}15.2 \\
(0.022)\end{array}$ & $\begin{array}{c}24.9 \\
(0.013)\end{array}$ \\
\hline 40 to 49 & $\begin{array}{c}22.1 \\
(0.058)\end{array}$ & $\begin{array}{c}27.1 \\
(0.036)\end{array}$ & $\begin{array}{c}15.9 \\
(0.011)\end{array}$ & $\begin{array}{c}23.5 \\
(0.045)\end{array}$ & $\begin{array}{c}26.5 \\
(0.027)\end{array}$ & $\begin{array}{c}16.5 \\
(0.011)\end{array}$ \\
\hline 50 to 59 & $\begin{array}{c}22.7 \\
(0.058)\end{array}$ & $\begin{array}{c}24.5 \\
(0.035)\end{array}$ & $\begin{array}{c}9.0 \\
(0.009)\end{array}$ & $\begin{array}{c}27.6 \\
(0.047)\end{array}$ & $\begin{array}{c}26.4 \\
(0.027)\end{array}$ & $\begin{array}{c}9.7 \\
(0.009)\end{array}$ \\
\hline 60 to 65 & $\begin{array}{c}13.9 \\
(0.048)\end{array}$ & $\begin{array}{c}12.4 \\
(0.027)\end{array}$ & $\begin{array}{c}3.5 \\
(0.006)\end{array}$ & $\begin{array}{c}14.7 \\
(0.037)\end{array}$ & $\begin{array}{c}11.8 \\
(0.020)\end{array}$ & $\begin{array}{c}3.5 \\
(0.006)\end{array}$ \\
\hline Female & $\begin{array}{c}50.2 \\
(0.069)\end{array}$ & $\begin{array}{c}54.8 \\
(0.040)\end{array}$ & $\begin{array}{c}50.6 \\
(0.015)\end{array}$ & $\begin{array}{c}54.6 \\
(0.052)\end{array}$ & $\begin{array}{c}57.2 \\
(0.030)\end{array}$ & $\begin{array}{c}49.3 \\
(0.015)\end{array}$ \\
\hline White & $\begin{array}{c}50.1 \\
(0.069)\end{array}$ & $\begin{array}{c}49.4 \\
(0.040)\end{array}$ & $\begin{array}{c}55.3 \\
(0.015)\end{array}$ & $\begin{array}{c}43.7 \\
(0.052)\end{array}$ & $\begin{array}{c}45.6 \\
(0.031)\end{array}$ & $\begin{array}{c}48.6 \\
(0.015)\end{array}$ \\
\hline Black & $\begin{array}{c}8.3 \\
(0.038)\end{array}$ & $\begin{array}{c}7.5 \\
(0.021) \\
\end{array}$ & $\begin{array}{c}6.5 \\
(0.007) \\
\end{array}$ & $\begin{array}{c}9.6 \\
(0.031) \\
\end{array}$ & $\begin{array}{c}8.6 \\
(0.017) \\
\end{array}$ & $\begin{array}{c}7.9 \\
(0.008) \\
\end{array}$ \\
\hline Yellow & $\begin{array}{c}0.3 \\
(0.008)\end{array}$ & $\begin{array}{c}0.4 \\
(0.005)\end{array}$ & $\begin{array}{c}0.5 \\
(0.002) \\
\end{array}$ & $\begin{array}{c}1.2 \\
(0.011)\end{array}$ & $\begin{array}{c}1.2 \\
(0.007)\end{array}$ & $\begin{array}{c}1.1 \\
(0.003)\end{array}$ \\
\hline Brown & $\begin{array}{c}40.1 \\
(0.068)\end{array}$ & $\begin{array}{c}41.6 \\
(0.040)\end{array}$ & $\begin{array}{c}36.8 \\
(0.015)\end{array}$ & $\begin{array}{c}45.1 \\
(0.052)\end{array}$ & $\begin{array}{c}44.3 \\
(0.031)\end{array}$ & $\begin{array}{c}42.0 \\
(0.015)\end{array}$ \\
\hline Indian & $\begin{array}{c}0.5 \\
(0.010)\end{array}$ & $\begin{array}{c}0.5 \\
(0.006)\end{array}$ & $\begin{array}{c}0.4 \\
(0.002)\end{array}$ & $\begin{array}{c}0.4 \\
(0.007)\end{array}$ & $\begin{array}{c}0.3 \\
(0.004)\end{array}$ & $\begin{array}{c}0.4 \\
(0.002)\end{array}$ \\
\hline
\end{tabular}

Source: Demographic Census, IBGE.

Working age population: 10 to 65 years. Average values in column \% for all nominal variables. Standard errors between parentheses. 
for nondisabled. In turn, the percentage of self-employed among severely disabled workers was 2.4 percentage points higher than that of the mildly disabled and 8.1 percentage points higher than that of nondisabled.

Largely reflecting their high share of self-employed workers, severely disabled workers relatively prevail in agricultural activities $(12.8 \%$ versus $10.3 \%$ of mildly disabled and $9.2 \%$ of nondisabled). The share of workers in the other precarious economic activity in Brazil - domestic work - is also higher among severely disabled workers: $10.7 \%$ as opposed to $9.4 \%$ for mildly disabled and $6.5 \%$ for nondisabled. On the other hand, the disabled workers are underrepresented, particularly, in the trade and repair sector: $15.8 \%$ for severely disabled and $15.9 \%$ for mildly disabled, versus $18.4 \%$ for nondisabled.

In spite of their most vulnerable occupational characteristics, the groups of people with severe and mild disabilities witnessed substantial improvements between 2000 and 2010. For example, the average wage of this group increased by $11 \%$, as opposed to $16 \%$ of mildly disabled and $4 \%$ of nondisabled. The percentage of formal severely disabled employees increased by 9 percentage points, as opposed to 10.5 percentage points of mildly disabled and 9.8 percentage points of nondisabled. Several factors may have contributed to this dynamic. The assessment of these determinants is fundamental in order to understand the effectiveness of social policies aimed at people with disabilities, especially employment quotas, which will be the subject of the next topics.

\subsection{The Determinants of Labor and Wages}

Six LPM were adjusted by OLS to assess the determinants of the differences in the labor force participation. The dependent variable is the binary variable employed ( 1 for employed and 0 for non-employed persons of working age). For each year, three equations were estimated, one for each group of disability (severely disabled, mildly disabled and nondisabled). The $p$ values are based on heteroscedasticity-consistent standard errors. Due to the substantial number of observations in the sample of the Demographic Census, which ranged from 521 thousand to 10.9 million, most estimates were statistically different from zero. Sample sizes differ slightly from those presented in Table 2 since observations with missing values for any of the variables were excluded in this analysis. The categories with the largest net impacts on the probability of employment are those associated with education, age and sex. For example, in 2010, holding constant other factors, the probability of being employed for the nondisabled with college education was 31 percentage points higher than that of the nondisabled with no education (reference category). The higher impact of the educational attainment on the chances of being employed for disabled persons must also be highlighted. This result may suggest a stricter selection criterion for disabled persons in the labor market, since only the most qualified workers with disabilities would be selected to fulfill the quotas that are reserved for them.

There is an inverted- $U$ relation between age and the probability of being employed for all groups of disability. In other words, holding constant other factors, the probability of being employed increases up to 30 and 49 year olds, when it begins to decline. Moreover, the impact of age on the chances of being employed is smaller for the severely disabled when compared to mildly disabled and nondisabled persons. This means that age is less important in 
Table 3: Average values of occupational characteristics

\begin{tabular}{|c|c|c|c|c|c|c|}
\hline \multirow{2}{*}{$\begin{array}{l}\text { Occupational } \\
\text { Characteristics }\end{array}$} & \multicolumn{3}{|c|}{2000} & \multicolumn{3}{|c|}{2010} \\
\hline & $\begin{array}{l}\text { Severely } \\
\text { Disabled }\end{array}$ & $\begin{array}{c}\text { Mildly } \\
\text { Disabled }\end{array}$ & $\begin{array}{c}\text { Non- } \\
\text { disabled }\end{array}$ & $\begin{array}{l}\text { Severely } \\
\text { Disabled }\end{array}$ & $\begin{array}{c}\text { Mildly } \\
\text { Disabled }\end{array}$ & $\begin{array}{c}\text { Non- } \\
\text { disabled }\end{array}$ \\
\hline Sample Size (1000) & 145,419 & 744,421 & $5,909,228$ & 334,040 & $1,427,605$ & $6,297,724$ \\
\hline Wage (R $\$ /$ Month) & $\begin{array}{c}880 \\
(11.393)\end{array}$ & $\begin{array}{c}1,062 \\
(3.511)\end{array}$ & $\begin{array}{l}1,259 \\
(1.727)\end{array}$ & $\begin{array}{c}975 \\
(4.234)\end{array}$ & $\begin{array}{l}1,231 \\
(2.759)\end{array}$ & $\begin{array}{l}1,314 \\
(1.214)\end{array}$ \\
\hline $20 \mathrm{~h}$ or Less & $\begin{array}{c}10.5 \\
(0.080)\end{array}$ & $\begin{array}{c}9.3 \\
(0.034)\end{array}$ & $\begin{array}{c}7.1 \\
(0.011)\end{array}$ & $\begin{array}{c}16.2 \\
(0.064)\end{array}$ & $\begin{array}{c}14.0 \\
(0.029)\end{array}$ & $\begin{array}{c}10.8 \\
(0.012)\end{array}$ \\
\hline 21 to $39 \mathrm{~h}$ & $\begin{array}{c}15.5 \\
(0.095)\end{array}$ & $\begin{array}{c}15.1 \\
(0.041)\end{array}$ & $\begin{array}{c}13.3 \\
(0.014)\end{array}$ & $\begin{array}{c}12.8 \\
(0.058)\end{array}$ & $\begin{array}{c}12.4 \\
(0.028) \\
\end{array}$ & $\begin{array}{c}10.9 \\
(0.012) \\
\end{array}$ \\
\hline 40 to $44 \mathrm{~h}$ & $\begin{array}{c}29.6 \\
(0.120)\end{array}$ & $\begin{array}{c}30.6 \\
(0.053)\end{array}$ & $\begin{array}{c}35.9 \\
(0.020)\end{array}$ & $\begin{array}{c}40.2 \\
(0.085)\end{array}$ & $\begin{array}{c}44.0 \\
(0.042)\end{array}$ & $\begin{array}{c}49.2 \\
(0.020)\end{array}$ \\
\hline $45 \mathrm{~h}$ or More & $\begin{array}{c}44.5 \\
(0.130)\end{array}$ & $\begin{array}{c}45.0 \\
(0.058)\end{array}$ & $\begin{array}{c}43.8 \\
(0.020)\end{array}$ & $\begin{array}{c}30.8 \\
(0.080)\end{array}$ & $\begin{array}{c}29.7 \\
(0.038)\end{array}$ & $\begin{array}{c}29.2 \\
(0.018)\end{array}$ \\
\hline Formal Employee & $\begin{array}{c}31.0 \\
(0.121)\end{array}$ & $\begin{array}{c}33.1 \\
(0.055)\end{array}$ & $\begin{array}{c}41.4 \\
(0.020)\end{array}$ & $\begin{array}{c}40.0 \\
(0.085)\end{array}$ & $\begin{array}{c}43.6 \\
(0.042)\end{array}$ & $\begin{array}{c}51.2 \\
(0.020)\end{array}$ \\
\hline Civil Servant & $\begin{array}{c}5.2 \\
(0.058)\end{array}$ & $\begin{array}{c}6.4 \\
(0.028)\end{array}$ & $\begin{array}{c}6.2 \\
(0.010)\end{array}$ & $\begin{array}{c}5.4 \\
(0.039)\end{array}$ & $\begin{array}{c}6.5 \\
(0.021)\end{array}$ & $\begin{array}{c}5.7 \\
(0.009)\end{array}$ \\
\hline Informal Employee & $\begin{array}{c}28.2 \\
(0.118)\end{array}$ & $\begin{array}{c}25.4 \\
(0.050)\end{array}$ & $\begin{array}{c}25.5 \\
(0.018)\end{array}$ & $\begin{array}{c}24.3 \\
(0.074)\end{array}$ & $\begin{array}{c}21.6 \\
(0.034)\end{array}$ & $\begin{array}{c}20.1 \\
(0.016)\end{array}$ \\
\hline Self-employed & $\begin{array}{c}33.5 \\
(0.124)\end{array}$ & $\begin{array}{c}32.3 \\
(0.054)\end{array}$ & $\begin{array}{c}23.8 \\
(0.018)\end{array}$ & $\begin{array}{c}29.0 \\
(0.079)\end{array}$ & $\begin{array}{c}26.6 \\
(0.037)\end{array}$ & $\begin{array}{c}20.9 \\
(0.016)\end{array}$ \\
\hline Employer & $\begin{array}{c}2.2 \\
(0.038)\end{array}$ & $\begin{array}{c}2.7 \\
(0.019)\end{array}$ & $\begin{array}{c}3.1 \\
(0.007)\end{array}$ & $\begin{array}{c}1.3 \\
(0.020)\end{array}$ & $\begin{array}{c}1.8 \\
(0.011)\end{array}$ & $\begin{array}{c}2.2 \\
(0.006)\end{array}$ \\
\hline Agriculture & $\begin{array}{c}19.1 \\
(0.103)\end{array}$ & $\begin{array}{c}17.1 \\
(0.044)\end{array}$ & $\begin{array}{c}12.2 \\
(0.013)\end{array}$ & $\begin{array}{c}12.8 \\
(0.058)\end{array}$ & $\begin{array}{c}10.3 \\
(0.025)\end{array}$ & $\begin{array}{c}9.2 \\
(0.011)\end{array}$ \\
\hline Manufacturing & $\begin{array}{c}12.5 \\
(0.087)\end{array}$ & $\begin{array}{c}12.8 \\
(0.039)\end{array}$ & $\begin{array}{c}14.5 \\
(0.014)\end{array}$ & $\begin{array}{c}11.3 \\
(0.055)\end{array}$ & $\begin{array}{c}11.4 \\
(0.027)\end{array}$ & $\begin{array}{c}12.9 \\
(0.013)\end{array}$ \\
\hline $\begin{array}{l}\text { Other Industrial } \\
\text { Activities }\end{array}$ & $\begin{array}{c}0.9 \\
(0.025)\end{array}$ & $\begin{array}{c}0.9 \\
(0.011)\end{array}$ & $\begin{array}{c}0.9 \\
(0.004)\end{array}$ & $\begin{array}{c}1.7 \\
(0.023)\end{array}$ & $\begin{array}{c}1.5 \\
(0.010)\end{array}$ & $\begin{array}{c}1.5 \\
(0.005)\end{array}$ \\
\hline Construction & $\begin{array}{c}8.0 \\
(0.071) \\
\end{array}$ & $\begin{array}{c}7.8 \\
(0.031)\end{array}$ & $\begin{array}{c}7.5 \\
(0.011)\end{array}$ & $\begin{array}{c}8.5 \\
(0.048) \\
\end{array}$ & $\begin{array}{c}7.7 \\
(0.022)\end{array}$ & $\begin{array}{c}7.8 \\
(0.011) \\
\end{array}$ \\
\hline Trade and Repair & $\begin{array}{c}15.5 \\
(0.095)\end{array}$ & $\begin{array}{c}15.2 \\
(0.042)\end{array}$ & $\begin{array}{c}17.7 \\
(0.016)\end{array}$ & $\begin{array}{c}15.8 \\
(0.063)\end{array}$ & $\begin{array}{c}15.9 \\
(0.031)\end{array}$ & $\begin{array}{c}18.4 \\
(0.015)\end{array}$ \\
\hline $\begin{array}{l}\text { Accommodation } \\
\text { and Food }\end{array}$ & $\begin{array}{c}5.6 \\
(0.060) \\
\end{array}$ & $\begin{array}{c}5.2 \\
(0.026) \\
\end{array}$ & $\begin{array}{c}4.7 \\
(0.009) \\
\end{array}$ & $\begin{array}{c}4.1 \\
(0.034) \\
\end{array}$ & $\begin{array}{c}3.7 \\
(0.016) \\
\end{array}$ & $\begin{array}{c}3.6 \\
(0.007) \\
\end{array}$ \\
\hline $\begin{array}{l}\text { Transportation, } \\
\text { Warehouse, } \\
\text { Communication }\end{array}$ & $\begin{array}{c}4.2 \\
(0.053)\end{array}$ & $\begin{array}{c}5.0 \\
(0.025)\end{array}$ & $\begin{array}{c}5.6 \\
(0.009)\end{array}$ & $\begin{array}{c}3.9 \\
(0.034)\end{array}$ & $\begin{array}{c}4.6 \\
(0.018)\end{array}$ & $\begin{array}{c}4.8 \\
(0.008)\end{array}$ \\
\hline $\begin{array}{l}\text { Public } \\
\text { Administration }\end{array}$ & $\begin{array}{c}5.3 \\
(0.059)\end{array}$ & $\begin{array}{c}6.0 \\
(0.028)\end{array}$ & $\begin{array}{c}5.9 \\
(0.010)\end{array}$ & $\begin{array}{c}5.3 \\
(0.039)\end{array}$ & $\begin{array}{c}6.2 \\
(0.020)\end{array}$ & $\begin{array}{c}5.7 \\
(0.009)\end{array}$ \\
\hline $\begin{array}{l}\text { Education, Health } \\
\text { and Social }\end{array}$ & $\begin{array}{c}7.9 \\
(0.071)\end{array}$ & $\begin{array}{c}9.4 \\
(0.034)\end{array}$ & $\begin{array}{c}10.0 \\
(0.012)\end{array}$ & $\begin{array}{c}9.0 \\
(0.050)\end{array}$ & $\begin{array}{c}10.8 \\
(0.026)\end{array}$ & $\begin{array}{c}10.1 \\
(0.012)\end{array}$ \\
\hline $\begin{array}{l}\text { Other Social and } \\
\text { Personal }\end{array}$ & $\begin{array}{c}4.1 \\
(0.052)\end{array}$ & $\begin{array}{c}3.9 \\
(0.023)\end{array}$ & $\begin{array}{c}3.9 \\
(0.008)\end{array}$ & $\begin{array}{c}3.8 \\
(0.033)\end{array}$ & $\begin{array}{c}4.4 \\
(0.017)\end{array}$ & $\begin{array}{c}4.7 \\
(0.008)\end{array}$ \\
\hline Domestic Service & $\begin{array}{c}9.5 \\
(0.077)\end{array}$ & $\begin{array}{c}9.1 \\
(0.033)\end{array}$ & $\begin{array}{c}8.0 \\
(0.011)\end{array}$ & $\begin{array}{c}10.7 \\
(0.054)\end{array}$ & $\begin{array}{c}9.4 \\
(0.024)\end{array}$ & $\begin{array}{c}6.5 \\
(0.010)\end{array}$ \\
\hline Other Activities & $\begin{array}{c}7.3 \\
(0.068)\end{array}$ & $\begin{array}{c}7.4 \\
(0.030)\end{array}$ & $\begin{array}{c}9.1 \\
(0.012)\end{array}$ & $\begin{array}{c}13.0 \\
(0.058)\end{array}$ & $\begin{array}{c}14.2 \\
(0.029)\end{array}$ & $\begin{array}{c}14.8 \\
(0.014)\end{array}$ \\
\hline
\end{tabular}

Source: Demographic Census, IBGE.

Employed population with positive earnings. Average values in $R \$$ for wage and column \%

for the nominal variables. Standard errors between parentheses.

${ }^{1}$ Wages at constant values of July 2010. 
determining employment opportunities for severely disabled persons, which can be related to the relatively low labor participation rates observed for those adults with disabilities.

Table 4: Ordinary least squares estimates for the binary dependent variable employed

\begin{tabular}{l|ccc|ccc}
\hline \multirow{4}{*}{ Variable } & \multicolumn{3}{|c|}{2000} & \multicolumn{3}{c}{ 2010 } \\
\cline { 2 - 7 } & $\begin{array}{c}\text { Severely } \\
\text { Disabled Disabled }\end{array}$ & $\begin{array}{c}\text { Mon- } \\
\text { disabled }\end{array}$ & $\begin{array}{c}\text { Severely } \\
\text { Disabled }\end{array}$ & $\begin{array}{c}\text { Mildly } \\
\text { Disabled }\end{array}$ & $\begin{array}{c}\text { Non- } \\
\text { disabled }\end{array}$ \\
\hline Intercept & 0.058 & 0.344 & 0.332 & 0.035 & 0.269 & 0.249 \\
& $(0.003)$ & $(0.002)$ & $(0.001)$ & $(0.003)$ & $(0.002)$ & $(0.001)$ \\
\hline Elementary & 0.142 & 0.070 & 0.078 & 0.185 & 0.107 & 0.124 \\
& $(0.001)$ & $(0.001)$ & $(0.001)$ & $(0.001)$ & $(0.001)$ & $(0.001)$ \\
\hline Middle & 0.297 & 0.185 & 0.173 & 0.339 & 0.213 & 0.217 \\
& $(0.003)$ & $(0.002)$ & $(0.001)$ & $(0.002)$ & $(0.001)$ & $(0.001)$ \\
\hline College & 0.447 & 0.301 & 0.272 & 0.500 & 0.328 & 0.310 \\
& $(0.004)$ & $(0.002)$ & $(0.001)$ & $(0.003)$ & $(0.002)$ & $(0.001)$ \\
\hline 20 to 29 & 0.142 & 0.274 & 0.307 & 0.229 & 0.335 & 0.352 \\
& $(0.002)$ & $(0.002)$ & $(0.000)$ & $(0.003)$ & $(0.002)$ & $(0.001)$ \\
\hline 30 to 39 & 0.193 & 0.342 & 0.395 & 0.309 & 0.425 & 0.452 \\
& $(0.002)$ & $(0.002)$ & $(0.000)$ & $(0.002)$ & $(0.002)$ & $(0.001)$ \\
\hline 40 to 49 & 0.222 & 0.320 & 0.382 & 0.340 & 0.420 & 0.454 \\
& $(0.002)$ & $(0.002)$ & $(0.001)$ & $(0.002)$ & $(0.001)$ & $(0.001)$ \\
\hline 50 to 59 & 0.166 & 0.201 & 0.253 & 0.272 & 0.309 & 0.345 \\
& $(0.002)$ & $(0.002)$ & $(0.001)$ & $(0.002)$ & $(0.002)$ & $(0.001)$ \\
\hline 60 to 65 & 0.062 & 0.036 & 0.080 & 0.130 & 0.110 & 0.141 \\
& $(0.002)$ & $(0.002)$ & $(0.001)$ & $(0.002)$ & $(0.002)$ & $(0.001)$ \\
\hline Female & -0.157 & -0.324 & -0.299 & -0.156 & -0.252 & -0.226 \\
& $(0.001)$ & $(0.001)$ & $(0.000)$ & $(0.001)$ & $(0.001)$ & $(0.000)$ \\
\hline Black & 0.030 & 0.022 & 0.024 & 0.040 & 0.030 & 0.020 \\
& $(0.002)$ & $(0.002)$ & $(0.001)$ & $(0.002)$ & $(0.001)$ & $(0.001)$ \\
\hline Yellow & -0.036 & -0.018 & -0.048 & 0.024 & -0.006 & -0.012 \\
& $(0.011)$ & $(0.006)$ & $(0.002)$ & $(0.006)$ & $(0.003)$ & $(0.002)$ \\
\hline Brown & 0.014 & 0.003 & 0.005 & 0.008 & -0.002 & -0.007 \\
& $(0.001)$ & $(0.001)$ & $(0.000)$ & $(0.001)$ & $(0.001)$ & $(0.000)$ \\
\hline R-square & 0.031 & -0.022 & -0.063 & 0.012 & -0.054 & -0.133 \\
& $(0.009)$ & $(0.006)$ & $(0.002)$ & $(0.009)$ & $(0.005)$ & $(0.002)$ \\
\hline Sougenous & $y e s$ & $y e s$ & $y e s$ & $y e s$ & $y e s$ & $y e s$ \\
& 520,597 & $1,534,326$ & $10,858,260$ & 904,451 & $2,644,458$ & $10,484,968$ \\
& 1,641 & 9,180 & 70,275 & 3,564 & 14,358 & 68,248 \\
& 0.109 & 0.189 & 0.202 & 0.133 & 0.175 & 0.203 \\
\hline
\end{tabular}

Source: Demographic Census, IBGE.

Working age population (15 to 65 years). Heteroscedasticity-consistent standard errors between parentheses.

+ Non-significant at $5 \%$.

Sex also plays an important role in the probability of being employed. Among nondisabled persons, the probability of a woman being employed was 
23 percentage points lower than that of a man in 2010. Among severely disabled persons, this difference was less meaningful (16 percentage points). In other words, the social division of labor between men and women is less apparent in the latter group. In turn, there is no remarkable difference in the net impacts of color or race on the probability of being employed among the groups of disability. Black workers tend to be slightly more likely to be employed, which may reflect the higher costs of unemployment that these workers are subjected to.

Between 2000 and 2010, the ER grew mainly among the less vulnerable socioeconomic groups, increasing inequalities in the access to jobs. The net effects of socioeconomic characteristics on the probability of being employed increased in most situations. For example, the net impacts of elementary, postsecondary, and superior education (when compared to no education, the reference of the analysis) increased among all groups of disability. A similar trend was observed in the case of net impact of age on the probability of being employed.

The determinants of differences in the average wages were analyzed by fitting six models with OLS, using the logarithm of the wage for employed workers as dependent variables (Table 5). Three equations were adjusted for each year, one for each group of disability (severely disabled, mildly disabled, and nondisabled). Sample sizes are slightly different from those presented in Table 3 because some observations were excluded due to missing values for any of the variables under analysis. The $p$ values are also based on heteroscedasticity-consistent standard errors. The R-squares range between $43.7 \%$ and $54.2 \%$, and most estimates are statistically different from zero at $5 \%$ significance level. Since analyses are based on log-linear models with dummy explanatory variables, the percentage change in wage for category 1 in comparison with the reference category 0 is equivalent to $100\left[e^{\beta_{j}}-1\right] \%$ (Halvorsen \& Palmquist 1980).

Educational attainment is the explanatory factor with the highest net impact on average wages. For example, nondisabled persons with college education had an average wage nearly three times higher $\left(e^{1.006}-1=173 \%\right)$ than that of the nondisabled with no education (reference category) in 2010, holding constant other characteristics. An interesting result is that the impact of both college and middle school education on the average wages tends to be higher among severely disabled and mildly disabled persons. As also witnessed in the probability of being employed, this result may suggest a stricter selection criterion for people with disabilities. In other words, employers would select just the most qualified workers among those with disabilities, thus increasing inequality in relation to those less qualified that remained excluded from the more structured labor market.

On the other hand, the marginal returns of age, which are associated both to differences between generations and to professional experience, are lower among the mildly disabled; all among severely disabled persons. Difficulties faced by those workers with disabilities in the labor market may help explain their low marginal returns: the lower the job stability, the lower the gains associated with professional experience.

Holding constant other factors, women, as well as black and brown workers have lower average wages than men, white (reference analysis), and yellow workers, with no substantial differences between the groups of disability.

Occupational characteristics are also responsible for important differences 
Table 5: Ordinary least squares estimates for the dependent variable log wage

\begin{tabular}{|c|c|c|c|c|c|c|}
\hline \multirow[b]{2}{*}{ Variable } & \multicolumn{3}{|c|}{2000} & \multicolumn{3}{|c|}{2010} \\
\hline & $\begin{array}{l}\text { Severely } \\
\text { Disabled }\end{array}$ & $\begin{array}{c}\text { Mildly } \\
\text { Disabled }\end{array}$ & $\begin{array}{c}\text { Non- } \\
\text { disabled }\end{array}$ & $\begin{array}{l}\text { Severely } \\
\text { Disabled }\end{array}$ & $\begin{array}{c}\text { Mildly } \\
\text { Disabled }\end{array}$ & $\begin{array}{c}\text { Non- } \\
\text { disabled }\end{array}$ \\
\hline Intercept & $\begin{array}{c}5.111 \\
(0.016)\end{array}$ & $\begin{array}{c}5.014 \\
(0.008)\end{array}$ & $\begin{array}{c}5.009 \\
(0.002)\end{array}$ & $\begin{array}{c}5.456 \\
(0.012)\end{array}$ & $\begin{array}{l}5.412 \\
(0.006)\end{array}$ & $\begin{array}{c}5.515 \\
(0.003)\end{array}$ \\
\hline Elementary & $\begin{array}{c}0.279 \\
(0.006)\end{array}$ & $\begin{array}{c}0.307 \\
(0.003)\end{array}$ & $\begin{array}{c}0.334 \\
(0.001)\end{array}$ & $\begin{array}{c}0.155 \\
(0.006)\end{array}$ & $\begin{array}{c}0.168 \\
(0.003)\end{array}$ & $\begin{array}{c}0.150 \\
(0.002)\end{array}$ \\
\hline Middle & $\begin{array}{c}0.757 \\
(0.009)\end{array}$ & $\begin{array}{c}0.779 \\
(0.004)\end{array}$ & $\begin{array}{c}0.709 \\
(0.002)\end{array}$ & $\begin{array}{c}0.453 \\
(0.007)\end{array}$ & $\begin{array}{c}0.462 \\
(0.004)\end{array}$ & $\begin{array}{c}0.387 \\
(0.002)\end{array}$ \\
\hline College & $\begin{array}{c}1.521 \\
(0.013)\end{array}$ & $\begin{array}{c}1.533 \\
(0.005)\end{array}$ & $\begin{array}{c}1.459 \\
(0.002)\end{array}$ & $\begin{array}{c}1.077 \\
(0.009)\end{array}$ & $\begin{array}{c}1.105 \\
(0.004)\end{array}$ & $\begin{array}{c}1.006 \\
(0.002)\end{array}$ \\
\hline 20 to 29 & $\begin{array}{c}0.346 \\
(0.010)\end{array}$ & $\begin{array}{c}0.413 \\
(0.005)\end{array}$ & $\begin{array}{c}0.408 \\
(0.001)\end{array}$ & $\begin{array}{c}0.279 \\
(0.009)\end{array}$ & $\begin{array}{c}0.307 \\
(0.004)\end{array}$ & $\begin{array}{c}0.314 \\
(0.001)\end{array}$ \\
\hline 30 to & $\begin{array}{c}0.562 \\
(0.010)\end{array}$ & $\begin{array}{c}0.645 \\
(0.005)\end{array}$ & $\begin{array}{c}0.681 \\
(0.001)\end{array}$ & $\begin{array}{c}0.471 \\
(0.009)\end{array}$ & $\begin{array}{c}0.541 \\
(0.004)\end{array}$ & $\begin{array}{c}0.558 \\
(0.001)\end{array}$ \\
\hline 40 to 49 & $\begin{array}{c}0.641 \\
(0.010)\end{array}$ & $\begin{array}{c}0.743 \\
(0.005)\end{array}$ & $\begin{array}{c}0.811 \\
(0.001)\end{array}$ & $\begin{array}{c}0.557 \\
(0.009)\end{array}$ & $\begin{array}{c}0.654 \\
(0.004)\end{array}$ & $\begin{array}{c}0.680 \\
(0.001)\end{array}$ \\
\hline$\overline{50}$ & $\begin{array}{c}0.626 \\
(0.011)\end{array}$ & $\begin{array}{c}0.733 \\
(0.005)\end{array}$ & $\begin{array}{c}0.827 \\
(0.002)\end{array}$ & $\begin{array}{c}0.593 \\
(0.009)\end{array}$ & $\begin{array}{c}0.709 \\
(0.004)\end{array}$ & $\begin{array}{c}0.762 \\
(0.002)\end{array}$ \\
\hline 60 to 65 & $\begin{array}{c}0.586 \\
(0.013)\end{array}$ & $\begin{array}{c}0.680 \\
(0.006)\end{array}$ & $\begin{array}{c}0.763 \\
(0.003)\end{array}$ & $\begin{array}{c}0.623 \\
(0.010)\end{array}$ & $\begin{array}{c}0.735 \\
(0.005)\end{array}$ & $\begin{array}{c}0.790 \\
(0.003)\end{array}$ \\
\hline$\overline{\mathrm{Fe}}$ & $\begin{array}{c}-0.319 \\
(0.005) \\
\end{array}$ & $\begin{array}{c}-0.400 \\
(0.002) \\
\end{array}$ & $\begin{array}{c}-0.340 \\
(0.001) \\
\end{array}$ & $\begin{array}{c}-0.306 \\
(0.004) \\
\end{array}$ & $\begin{array}{c}-0.347 \\
(0.002) \\
\end{array}$ & $\begin{array}{c}-0.296 \\
(0.001) \\
\end{array}$ \\
\hline Black & $\begin{array}{c}-0.147 \\
(0.008) \\
\end{array}$ & $\begin{array}{c}-0.152 \\
(0.003) \\
\end{array}$ & $\begin{array}{c}-0.167 \\
(0.001) \\
\end{array}$ & $\begin{array}{c}-0.116 \\
(0.005) \\
\end{array}$ & $\begin{array}{c}-0.143 \\
(0.002) \\
\end{array}$ & $\begin{array}{c}-0.151 \\
(0.001) \\
\end{array}$ \\
\hline Yellow & $\begin{array}{c}0.094 \\
(0.044) \\
\end{array}$ & $\begin{array}{c}0.179 \\
(0.017) \\
\end{array}$ & $\begin{array}{c}0.182 \\
(0.005) \\
\end{array}$ & $\begin{array}{r}0.009^{*} \\
(0.015) \\
\end{array}$ & $\begin{array}{c}0.017 \\
(0.007) \\
\end{array}$ & $\begin{array}{c}0.014 \\
(0.003) \\
\end{array}$ \\
\hline Brown & $\begin{array}{c}-0.130 \\
(0.005) \\
\end{array}$ & $\begin{array}{c}-0.125 \\
(0.002)\end{array}$ & $\begin{array}{c}-0.133 \\
(0.001)\end{array}$ & $\begin{array}{c}-0.116 \\
(0.003)\end{array}$ & $\begin{array}{r}-0.136 \\
(0.002)\end{array}$ & $\begin{array}{c}-0.137 \\
(0.001)\end{array}$ \\
\hline Indian & $\begin{array}{c}-0.137 \\
(0.030)\end{array}$ & $\begin{array}{c}-0.095 \\
(0.013)\end{array}$ & $\begin{array}{c}-0.124 \\
(0.006)\end{array}$ & $\begin{array}{c}-0.210 \\
(0.025)\end{array}$ & $\begin{array}{c}-0.221 \\
(0.013)\end{array}$ & $\begin{array}{c}-0.223 \\
(0.007)\end{array}$ \\
\hline 21 to $39 \mathrm{~h}$ & $\begin{array}{c}0.311 \\
(0.010)\end{array}$ & $\begin{array}{c}0.314 \\
(0.004)\end{array}$ & $\begin{array}{c}0.311 \\
(0.002)\end{array}$ & $\begin{array}{c}0.191 \\
(0.006)\end{array}$ & $\begin{array}{c}0.166 \\
(0.003)\end{array}$ & $\begin{array}{c}0.156 \\
(0.002)\end{array}$ \\
\hline 40 to $44 \mathrm{~h}$ & $\begin{array}{c}0.497 \\
(0.009)\end{array}$ & $\begin{array}{c}0.506 \\
(0.004)\end{array}$ & $\begin{array}{c}0.496 \\
(0.001)\end{array}$ & $\begin{array}{c}0.376 \\
(0.005)\end{array}$ & $\begin{array}{c}0.346 \\
(0.002)\end{array}$ & $\begin{array}{c}0.338 \\
(0.001)\end{array}$ \\
\hline $45 \mathrm{~h}$ or More & $\begin{array}{c}0.574 \\
(0.009)\end{array}$ & $\begin{array}{c}0.574 \\
(0.004)\end{array}$ & $\begin{array}{c}0.559 \\
(0.001)\end{array}$ & $\begin{array}{c}0.456 \\
(0.005)\end{array}$ & $\begin{array}{c}0.423 \\
(0.003)\end{array}$ & $\begin{array}{c}0.408 \\
(0.001)\end{array}$ \\
\hline Civil Servant & $\begin{array}{c}0.016^{*} \\
(0.010)\end{array}$ & $\begin{array}{c}0.031 \\
(0.004)\end{array}$ & $\begin{array}{c}0.044 \\
(0.001)\end{array}$ & $\begin{array}{c}0.105 \\
(0.008)\end{array}$ & $\begin{array}{c}0.138 \\
(0.003)\end{array}$ & $\begin{array}{c}0.149 \\
(0.002)\end{array}$ \\
\hline $\begin{array}{l}\text { Informal } \\
\text { Employee }\end{array}$ & $\begin{array}{c}-0.366 \\
(0.005)\end{array}$ & $\begin{array}{c}-0.301 \\
(0.002)\end{array}$ & $\begin{array}{c}-0.259 \\
(0.001)\end{array}$ & $\begin{array}{c}-0.382 \\
(0.004)\end{array}$ & $\begin{array}{c}-0.324 \\
(0.002)\end{array}$ & $\begin{array}{c}-0.304 \\
(0.001)\end{array}$ \\
\hline Self-employed & $\begin{array}{c}-0.216 \\
(0.006)\end{array}$ & $\begin{array}{c}-0.122 \\
(0.003)\end{array}$ & $\begin{array}{c}-0.023 \\
(0.001)\end{array}$ & $\begin{array}{c}-0.284 \\
(0.004)\end{array}$ & $\begin{array}{c}-0.170 \\
(0.002)\end{array}$ & $\begin{array}{c}-0.083 \\
(0.001)\end{array}$ \\
\hline
\end{tabular}

Source: Demographic Census, IBGE.

Employed population with positive earnings. Heteroscedasticity-consistent standard errors between parentheses.

Non-significant at $5 \%$. 
Table 5: Maximum likelihood estimates of the sample selection model for the dependent variable log wage (continuation)

\begin{tabular}{|c|c|c|c|c|c|c|}
\hline \multirow[b]{2}{*}{ Variable } & \multicolumn{3}{|c|}{2000} & \multicolumn{3}{|c|}{2010} \\
\hline & $\begin{array}{l}\text { Severely } \\
\text { Disabled }\end{array}$ & $\begin{array}{c}\text { Mildly } \\
\text { Disabled }\end{array}$ & $\begin{array}{c}\text { Non- } \\
\text { disabled }\end{array}$ & $\begin{array}{l}\text { Severely } \\
\text { Disabled }\end{array}$ & $\begin{array}{c}\text { Mildly } \\
\text { d Disabled }\end{array}$ & $\begin{array}{c}\text { Non- } \\
\text { disabled }\end{array}$ \\
\hline Employer & $\begin{array}{c}0.918 \\
(0.021)\end{array}$ & $\begin{array}{c}0.934 \\
(0.008)\end{array}$ & $\begin{array}{c}0.912 \\
(0.003)\end{array}$ & $\begin{array}{c}0.722 \\
(0.019)\end{array}$ & $\begin{array}{c}0.717 \\
(0.007)\end{array}$ & $\begin{array}{c}0.711 \\
(0.003)\end{array}$ \\
\hline$\overline{\text { Manufacturing }}$ & $\begin{array}{c}0.310 \\
(0.008) \\
\end{array}$ & $\begin{array}{c}0.394 \\
(0.004) \\
\end{array}$ & $\begin{array}{c}0.392 \\
(0.001) \\
\end{array}$ & $\begin{array}{c}0.355 \\
(0.006) \\
\end{array}$ & $\begin{array}{c}0.411 \\
(0.003) \\
\end{array}$ & $\begin{array}{c}0.387 \\
(0.001) \\
\end{array}$ \\
\hline Other Industrial & $\begin{array}{c}0.534 \\
(0.024)\end{array}$ & $\begin{array}{c}0.627 \\
(0.010)\end{array}$ & $\begin{array}{l}0.596 \\
(0.003)\end{array}$ & $\begin{array}{c}0.279 \\
(0.014)\end{array}$ & $\begin{array}{c}0.466 \\
(0.007)\end{array}$ & $\begin{array}{c}0.488 \\
(0.003)\end{array}$ \\
\hline Construction & $\begin{array}{c}0.351 \\
(0.009)\end{array}$ & $\begin{array}{c}0.371 \\
(0.004)\end{array}$ & $\begin{array}{c}0.358 \\
(0.001)\end{array}$ & $\begin{array}{c}0.415 \\
(0.006)\end{array}$ & $\begin{array}{c}0.418 \\
(0.003)\end{array}$ & $\begin{array}{c}0.375 \\
(0.001)\end{array}$ \\
\hline $\begin{array}{l}\text { Trade and } \\
\text { Repair }\end{array}$ & $\begin{array}{c}0.335 \\
(0.008)\end{array}$ & $\begin{array}{c}0.428 \\
(0.004)\end{array}$ & $\begin{array}{c}0.411 \\
(0.001)\end{array}$ & $\begin{array}{c}0.381 \\
(0.006)\end{array}$ & $\begin{array}{c}0.425 \\
(0.003)\end{array}$ & $\begin{array}{c}0.369 \\
(0.001)\end{array}$ \\
\hline $\begin{array}{l}\text { Accommodation, } \\
\text { Food }\end{array}$ & $\begin{array}{c}0.298 \\
(0.012)\end{array}$ & $\begin{array}{c}0.373 \\
(0.005)\end{array}$ & $\begin{array}{c}0.354 \\
(0.002)\end{array}$ & $\begin{array}{c}0.371 \\
(0.008)\end{array}$ & $\begin{array}{c}0.390 \\
(0.004)\end{array}$ & $\begin{array}{c}0.330 \\
(0.002)\end{array}$ \\
\hline $\begin{array}{l}\text { Transportation, } \\
\text { Warehouse, } \\
\text { Communication }\end{array}$ & $\begin{array}{l}0.530 \\
(0.012)\end{array}$ & $\begin{array}{c}0.624 \\
(0.005)\end{array}$ & $\begin{array}{c}0.585 \\
(0.002)\end{array}$ & $\begin{array}{c}0.524 \\
(0.009)\end{array}$ & $\begin{array}{l}0.572 \\
(0.004)\end{array}$ & $\begin{array}{c}0.489 \\
(0.002)\end{array}$ \\
\hline $\begin{array}{l}\text { Public } \\
\text { Administration }\end{array}$ & $\begin{array}{c}0.434 \\
(0.011) \\
\end{array}$ & $\begin{array}{c}0.538 \\
(0.005) \\
\end{array}$ & $\begin{array}{c}0.549 \\
(0.002) \\
\end{array}$ & $\begin{array}{c}0.599 \\
(0.008) \\
\end{array}$ & $\begin{array}{c}0.647 \\
(0.004) \\
\end{array}$ & $\begin{array}{c}0.560 \\
(0.002) \\
\end{array}$ \\
\hline $\begin{array}{l}\text { Education, } \\
\text { Health, } \\
\text { Social }\end{array}$ & $\begin{array}{l}0.414 \\
(0.010)\end{array}$ & $\begin{array}{c}0.487 \\
(0.004)\end{array}$ & $\begin{array}{c}0.458 \\
(0.002)\end{array}$ & $\begin{array}{c}0.483 \\
(0.007)\end{array}$ & $\begin{array}{l}0.491 \\
(0.004)\end{array}$ & $\begin{array}{c}0.423 \\
(0.002)\end{array}$ \\
\hline $\begin{array}{l}\text { Other Social, } \\
\text { Personal }\end{array}$ & $\begin{array}{c}0.297 \\
(0.012) \\
\end{array}$ & $\begin{array}{c}0.384 \\
(0.006) \\
\end{array}$ & $\begin{array}{c}0.406 \\
(0.002) \\
\end{array}$ & $\begin{array}{c}0.455 \\
(0.009) \\
\end{array}$ & $\begin{array}{c}0.485 \\
(0.004) \\
\end{array}$ & $\begin{array}{c}0.426 \\
(0.002) \\
\end{array}$ \\
\hline $\begin{array}{l}\text { Domestic } \\
\text { Service }\end{array}$ & $\begin{array}{c}0.164 \\
(0.009) \\
\end{array}$ & $\begin{array}{c}0.232 \\
(0.004) \\
\end{array}$ & $\begin{array}{c}0.189 \\
(0.001) \\
\end{array}$ & $\begin{array}{c}0.210 \\
(0.006) \\
\end{array}$ & $\begin{array}{c}0.242 \\
(0.003) \\
\end{array}$ & $\begin{array}{c}0.172 \\
(0.002) \\
\end{array}$ \\
\hline Other Activities & $\begin{array}{c}0.376 \\
(0.010)\end{array}$ & $\begin{array}{c}0.460 \\
(0.005)\end{array}$ & $\begin{array}{c}0.492 \\
(0.001)\end{array}$ & $\begin{array}{c}0.448 \\
(0.006)\end{array}$ & $\begin{array}{c}0.501 \\
(0.003)\end{array}$ & $\begin{array}{c}0.453 \\
(0.001)\end{array}$ \\
\hline Federal Units & yes & yes & yes & yes & yes & yes \\
\hline Sample Size & 144,992 & 742,382 & $5,890,724$ & 334,040 & $1,427,605$ & $6,297,724$ \\
\hline F Statistic & 2,249 & 13,111 & 12,260 & 4,546 & 21,683 & 99,162 \\
\hline R-square & 0.469 & 0.502 & 0.542 & 0.437 & 0.464 & 0.473 \\
\hline
\end{tabular}

Source: Demographic Census, IBGE.

Wage equation with sample selection correction. Estimates of the selection model are presented on Appendix B. Standard errors between parentheses.

* Non-significant at $5 \%$. 
between the average wages of the groups of disability. For example, the average wage of severely disabled persons working between 40 and 44 hours per week was $46 \%\left(e^{0.376}-1\right)$ higher than that of their counterparts working 20 hours or less per week (reference of analysis). For the mildly disabled and nondisabled, the differences were slightly lower, respectively $41 \%$ and $40 \%$. The working hours contribute to the wage in two ways: higher job supply and productivity gains. The higher marginal returns of working hour for severely disabled workers may be a result of the lack of decent opportunities for most workers in this group. Those with regular working hours earn substantially more than those working 20 hours or less per week (even when compared to other groups of disability), but the latter group is overrepresented among people with disabilities.

Average wages of informal employees and self-employed workers are substantially lower than that of formal workers (reference of analysis), civil servants and employers. The differences related to more vulnerable positions (informal and self-employed) are higher among disabled workers, probably because people with disabilities are subjected to excessively low earnings in the less structured labor market. For example, among severely disabled workers, the average wage of informal employees was $32 \%\left(e^{-0.382}-1\right)$ lower than that of formal employees in 2010 . This difference was equal to $28 \%$ among mildly the disabled and $26 \%$ among the nondisabled.

Estimates for the economic sectors highlight that the average wages of agricultural workers (reference of analysis) and domestic workers were substantially lower than that of workers in other sectors. The former is precisely the sector where people with disabilities are over-represented. On the other hand, workers in public administration are in a more favorable position, especially among nondisabled workers.

Most estimates reduced in value between 2000 and 2010, suggesting lower levels of wage inequalities between the socioeconomic groups. For example, holding constant other factors, the difference between the average wage of severely disabled workers with college education and no education decreased from $358 \%\left(e^{1.521}-1\right)$ in 2000 to $194 \%\left(e^{1.077}-1\right)$ in 2010 . The difference between nondisabled aged 40 to 49 and those aged 15 to 19 decreased from $125 \%\left(e^{0.881}-1\right)$ in 2000 to $97 \%\left(e^{0.680}-1\right)$ in 2010 . And differences between black and white decreased from $14 \%\left(e^{-0.147}-1\right)$ in 2000 to $-11 \%\left(e^{-0.116}-1\right)$ in 2010 among severely disabled workers.

Table 6 presents the estimates for the wage equation accounting for sample selection bias (Equation 2). The selection model estimates are presented in Appendix B. The method of estimation for models of sample selection correction consumes reasonable CPU time and memory, and estimates are not easily obtained for large data sets (which is the case of the sample of nondisabled persons). As a result, the estimates for the group of nondisabled workers refer to a $30 \%$ randomly selected sample. The number of observations and the statistic of goodness of fit (log likelihood) for each model are presented in the bottom lines of Table 6 . Both models (selection and wage equation) were fitted using the method of Maximum Likelihood.

The positive estimates for the coefficient $\lambda$ indicate a positive selectivity for all groups of disability. In other words, those workers in waged employment get higher wages than a random drawing from the WAP with comparable characteristics. The selectivity bias is greater in the case of severely disabled and nondisabled workers. In other words, unobserved differences 
Table 6: Maximum likelihood estimates of the sample selection model for the dependent variable log wage

\begin{tabular}{|c|c|c|c|c|c|c|}
\hline \multirow[b]{2}{*}{ Variable } & \multicolumn{3}{|c|}{2000} & \multicolumn{3}{|c|}{2010} \\
\hline & $\begin{array}{l}\text { Severely } \\
\text { Disabled }\end{array}$ & $\begin{array}{c}\text { Mildly } \\
\text { Disabled }\end{array}$ & $\begin{array}{c}\text { Non- } \\
\text { disabled }\end{array}$ & $\begin{array}{l}\text { Severely } \\
\text { Disabled }\end{array}$ & $\begin{array}{c}\text { Mildly } \\
\text { Disabled }\end{array}$ & $\begin{array}{c}\text { Non- } \\
\text { disabled }\end{array}$ \\
\hline Intercept & $\begin{array}{c}2.295 \\
(0.187) \\
\end{array}$ & $\begin{array}{c}4.606 \\
(0.025)\end{array}$ & $\begin{array}{c}4.005 \\
(0.014) \\
\end{array}$ & $\begin{array}{c}4.425 \\
(0.089) \\
\end{array}$ & $\begin{array}{c}5.133 \\
(0.018) \\
\end{array}$ & $\begin{array}{c}4.733 \\
(0.014) \\
\end{array}$ \\
\hline Elementary & $\begin{array}{c}0.862 \\
(0.039) \\
\end{array}$ & $\begin{array}{c}0.353 \\
(0.004) \\
\end{array}$ & $\begin{array}{c}0.449 \\
(0.003) \\
\end{array}$ & $\begin{array}{c}0.399 \\
(0.021) \\
\end{array}$ & $\begin{array}{c}0.210 \\
(0.004) \\
\end{array}$ & $\begin{array}{c}0.278 \\
(0.004) \\
\end{array}$ \\
\hline Middle & $\begin{array}{c}1.800 \\
(0.070) \\
\end{array}$ & $\begin{array}{c}0.889 \\
(0.008) \\
\end{array}$ & $\begin{array}{c}0.948 \\
(0.004) \\
\end{array}$ & $\begin{array}{c}0.844 \\
(0.034) \\
\end{array}$ & $\begin{array}{c}0.539 \\
(0.006) \\
\end{array}$ & $\begin{array}{c}0.602 \\
(0.005) \\
\end{array}$ \\
\hline$\overline{\text { College }}$ & $\begin{array}{c}2.915 \\
(0.093) \\
\end{array}$ & $\begin{array}{c}1.703 \\
(0.011) \\
\end{array}$ & $\begin{array}{c}1.823 \\
(0.006) \\
\end{array}$ & $\begin{array}{c}1.601 \\
(0.046) \\
\end{array}$ & $\begin{array}{c}1.218 \\
(0.008) \\
\end{array}$ & $\begin{array}{c}1.298 \\
(0.006) \\
\end{array}$ \\
\hline 20 to 29 & $\begin{array}{c}0.930 \\
(0.040) \\
\end{array}$ & $\begin{array}{c}0.597 \\
(0.012) \\
\end{array}$ & $\begin{array}{c}0.904 \\
(0.007) \\
\end{array}$ & $\begin{array}{c}0.573 \\
(0.027) \\
\end{array}$ & $\begin{array}{c}0.441 \\
(0.009) \\
\end{array}$ & $\begin{array}{c}0.692 \\
(0.007) \\
\end{array}$ \\
\hline 30 to 39 & $\begin{array}{c}1.314 \\
(0.051)\end{array}$ & $\begin{array}{c}0.866 \\
(0.014)\end{array}$ & $\begin{array}{c}1.294 \\
(0.008)\end{array}$ & $\begin{array}{c}0.844 \\
(0.033) \\
\end{array}$ & $\begin{array}{c}0.704 \\
(0.011)\end{array}$ & $\begin{array}{c}1.027 \\
(0.008)\end{array}$ \\
\hline 40 to 49 & $\begin{array}{c}1.488 \\
(0.057)\end{array}$ & $\begin{array}{c}0.952 \\
(0.013)\end{array}$ & $\begin{array}{c}1.406 \\
(0.008)\end{array}$ & $\begin{array}{c}0.961 \\
(0.036)\end{array}$ & $\begin{array}{c}0.817 \\
(0.011)\end{array}$ & $\begin{array}{c}1.150 \\
(0.008)\end{array}$ \\
\hline 50 to 59 & $\begin{array}{c}1.299 \\
(0.046)\end{array}$ & $\begin{array}{c}0.874 \\
(0.010)\end{array}$ & $\begin{array}{c}1.245 \\
(0.006)\end{array}$ & $\begin{array}{c}0.932 \\
(0.030)\end{array}$ & $\begin{array}{c}0.834 \\
(0.009)\end{array}$ & $\begin{array}{c}1.139 \\
(0.007)\end{array}$ \\
\hline 60 to 65 & $\begin{array}{c}0.809 \\
(0.019)\end{array}$ & $\begin{array}{c}0.702 \\
(0.006)\end{array}$ & $\begin{array}{c}0.910 \\
(0.004)\end{array}$ & $\begin{array}{c}0.789 \\
(0.017)\end{array}$ & $\begin{array}{c}0.784 \\
(0.005)\end{array}$ & $\begin{array}{c}0.964 \\
(0.005)\end{array}$ \\
\hline$\overline{\text { Female }}$ & $\begin{array}{c}-0.874 \\
(0.037)\end{array}$ & $\begin{array}{c}-0.589 \\
(0.011)\end{array}$ & $\begin{array}{c}-0.753 \\
(0.006)\end{array}$ & $\begin{array}{c}-0.467 \\
(0.014)\end{array}$ & $\begin{array}{c}-0.431 \\
(0.005)\end{array}$ & $\begin{array}{c}-0.505 \\
(0.004)\end{array}$ \\
\hline Black & $\begin{array}{c}-0.032 \\
(0.011)\end{array}$ & $\begin{array}{c}-0.139 \\
(0.004)\end{array}$ & $\begin{array}{c}-0.133 \\
(0.002)\end{array}$ & $\begin{array}{c}-0.072 \\
(0.006)\end{array}$ & $\begin{array}{c}-0.133 \\
(0.002)\end{array}$ & $\begin{array}{c}-0.130 \\
(0.002)\end{array}$ \\
\hline Yellow & $\begin{array}{c}-0.020^{*} \\
(0.034) \\
\end{array}$ & $\begin{array}{c}0.169 \\
(0.013) \\
\end{array}$ & $\begin{array}{c}0.115 \\
(0.007) \\
\end{array}$ & $\begin{array}{c}0.035 \\
(0.011) \\
\end{array}$ & $\begin{array}{c}0.015 \\
(0.005) \\
\end{array}$ & $\begin{array}{r}-0.005^{*} \\
(0.005) \\
\end{array}$ \\
\hline$\overline{\text { Brown }}$ & $\begin{array}{c}-0.076 \\
(0.006) \\
\end{array}$ & $\begin{array}{c}-0.123 \\
(0.002) \\
\end{array}$ & $\begin{array}{c}-0.127 \\
(0.001) \\
\end{array}$ & $\begin{array}{c}-0.107 \\
(0.003) \\
\end{array}$ & $\begin{array}{c}-0.136 \\
(0.001) \\
\end{array}$ & $\begin{array}{c}-0.142 \\
(0.001) \\
\end{array}$ \\
\hline Indigenous & $\begin{array}{c}-0.016^{*} \\
(0.028)\end{array}$ & $\begin{array}{c}-0.109 \\
(0.012)\end{array}$ & $\begin{array}{c}-0.239 \\
(0.009)\end{array}$ & $\begin{array}{c}-0.197 \\
(0.019)\end{array}$ & $\begin{array}{c}-0.241 \\
(0.011)\end{array}$ & $\begin{array}{c}-0.366 \\
(0.010)\end{array}$ \\
\hline 21 to $39 \mathrm{~h}$ & $\begin{array}{c}0.312 \\
(0.008) \\
\end{array}$ & $\begin{array}{c}0.315 \\
(0.004) \\
\end{array}$ & $\begin{array}{c}0.307 \\
(0.002) \\
\end{array}$ & $\begin{array}{c}0.192 \\
(0.005) \\
\end{array}$ & $\begin{array}{c}0.166 \\
(0.002) \\
\end{array}$ & $\begin{array}{c}0.158 \\
(0.002) \\
\end{array}$ \\
\hline 40 to $44 \mathrm{~h}$ & $\begin{array}{c}0.498 \\
(0.007)\end{array}$ & $\begin{array}{c}0.507 \\
(0.003)\end{array}$ & $\begin{array}{c}0.495 \\
(0.002)\end{array}$ & $\begin{array}{c}0.377 \\
(0.004)\end{array}$ & $\begin{array}{c}0.346 \\
(0.002) \\
\end{array}$ & $\begin{array}{c}0.338 \\
(0.002) \\
\end{array}$ \\
\hline $45 \mathrm{~h}$ or more & $\begin{array}{c}0.576 \\
(0.007)\end{array}$ & $\begin{array}{c}0.575 \\
(0.003)\end{array}$ & $\begin{array}{c}0.556 \\
(0.002)\end{array}$ & $\begin{array}{c}0.457 \\
(0.004)\end{array}$ & $\begin{array}{c}0.424 \\
(0.002)\end{array}$ & $\begin{array}{c}0.407 \\
(0.002)\end{array}$ \\
\hline Civil Servant & $\begin{array}{r}0.016^{*} \\
(0.011)\end{array}$ & $\begin{array}{c}0.032 \\
(0.004)\end{array}$ & $\begin{array}{c}0.046 \\
(0.003)\end{array}$ & $\begin{array}{c}0.105 \\
(0.007)\end{array}$ & $\begin{array}{c}0.138 \\
(0.003)\end{array}$ & $\begin{array}{c}0.146 \\
(0.003)\end{array}$ \\
\hline $\begin{array}{l}\text { Informal } \\
\text { Employee }\end{array}$ & $\begin{array}{c}-0.366 \\
(0.006)\end{array}$ & $\begin{array}{c}-0.301 \\
(0.002)\end{array}$ & $\begin{array}{c}-0.260 \\
(0.001)\end{array}$ & $\begin{array}{c}-0.382 \\
(0.003)\end{array}$ & $\begin{array}{c}-0.324 \\
(0.002)\end{array}$ & $\begin{array}{c}-0.304 \\
(0.001)\end{array}$ \\
\hline Self-employed & $\begin{array}{c}-0.217 \\
(0.006)\end{array}$ & $\begin{array}{c}-0.123 \\
(0.002)\end{array}$ & $\begin{array}{c}-0.027 \\
(0.001)\end{array}$ & $\begin{array}{c}-0.285 \\
(0.003)\end{array}$ & $\begin{array}{c}-0.170 \\
(0.002)\end{array}$ & $\begin{array}{c}-0.085 \\
(0.001)\end{array}$ \\
\hline
\end{tabular}

Source: Demographic Census, IBGE.

Wage equation with sample selection correction. Estimates of the selection model are presented in Appendix B. Standard errors between parentheses.

* Non-significant at $5 \%$. 
Table 6: Maximum likelihood estimates of the sample selection model for the dependent variable log wage (continuation)

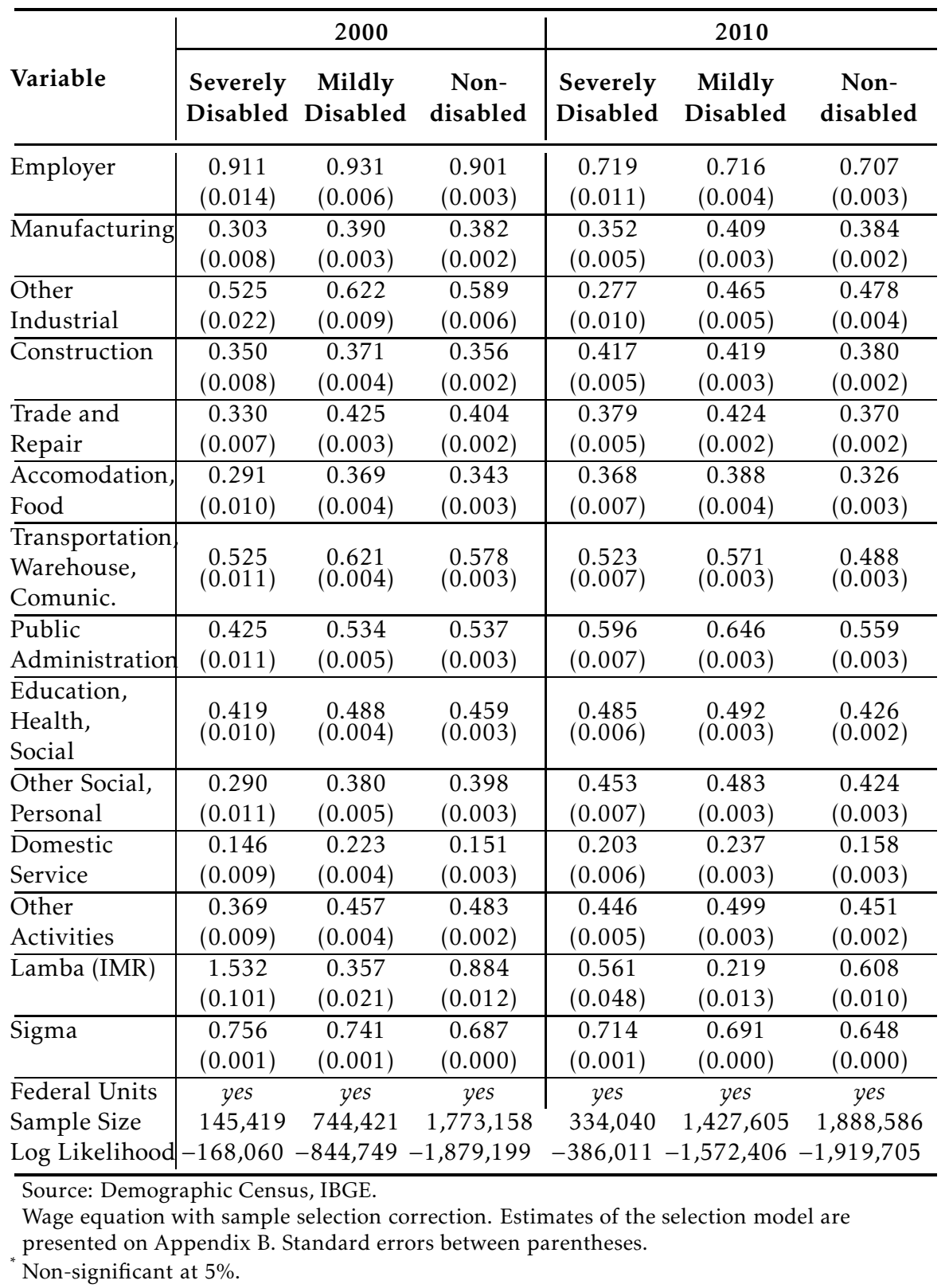


between employed and non-employed individuals have a larger impact on average income for severely disabled and nondisabled than for mildly disabled workers. Professional skills and perseverance, for example, can be some of these unobservable factors affecting simultaneously and positively employment and wage.

Some remarkable differences between estimates with and without sample selection correction (Tables 5 and 6 ) are the net impacts of socioeconomic characteristics (education, age, sex, and rac/color), which are substantially larger in the models accounting for sample selection. For example, in 2010, the net impact of college education on log wage for nondisabled persons is 1.006 in the model without correction (average wage 173\% higher than that of the nondisabled with no education) and 1.298 in the model with correction (average wage $266 \%$ higher). The log wage of severely disabled female workers is 0.306 points lower than that of severely disabled male workers (average wage $26 \%$ lower) in the model without correction, and 0.467 points lower in the model with correction (average wage 37\% lower). In other words, socioeconomic inequalities are even greater when taking into account the selectivity that employed populations are subjected to. Since the selectivity bias is higher for severely and nondisabled workers, differences between the impacts of observable and unobservable factors on income tend to be higher in this group.

\subsection{Decomposing the Impacts of Employment Quotas}

This topic decomposes changes in the differences of ER and average wages between the groups of disability into observable and unobservable factors. Two decompositions are presented for the differences between average wages: with and without sample selection correction. Since the simple comparison between the groups of disabled and nondisabled persons would ignore the numerous sources of heterogeneity that exist within the former group, three comparisons are made for each indicator: (i) severely disabled and mildly disabled; (ii) severely disabled and nondisabled; (iii) mildly disabled and nondisabled. The first comparison, between the severely and the mildly disabled, may be interpreted as the exclusive effect of the program on those with more severe functional limitations, which would present more restrictions to find a job and be more affected by discrimination. In turn, the comparison between the severely disabled and the nondisabled can be interpreted as the maximum potential impact of employment quotas, since it compares the groups of disability in more extreme conditions. Finally, the last comparison, between the mildly disabled and nondisabled, measures to what extent employment quotas would benefit those with less severe disabilities. Understanding the differences between the groups of disability will provide further insights into the causes of the disadvantage faced by this population.

The total difference between the ER of severely disabled and nondisabled persons was equal to 22.5 percentage points in 2010 (Table 7). The larger share of this difference ( 15.8 percentage points) was due to differences in the marginal effects of the socioeconomic characteristics. In other words, unobservable factors represented by the effect of coefficients was the main factor responsible for differences in the ER between disabled and nondisabled persons. The other 6.7 percentage points were due to socioeconomic differences between these groups of disability (effect of characteristics), i.e., due to 
the higher socioeconomic vulnerability of disabled in comparison with nondisabled persons. The main factor explaining the effect of characteristics is education, since this main determinant of occupational attainment presents substantially lower values among disabled persons.

Similar results were observed for the differences between severely and mildly disabled persons, albeit to a lesser extent: a total difference of 17.2 percentage points between the ER of disabled and mildly disabled persons in 2010, which was mainly due to unobservable factors ( 13.7 percentage points due to the effect of coefficients). In turn, the differences between the ER of mildly disabled and nondisabled persons was small (5.3 percentage points in 2010) and equally distributed between observable and unobservable factors.

Between 2000 and 2010, the difference between the ER of disabled and nondisabled persons, as well as between the disabled and mildly disabled reduced substantially: 4.4 and 3.7 percentage points, respectively. This reduction was almost exclusively due to the effect of coefficients, i.e., due to unobserved factors such as social discrimination and physical difficulties in accessing the job. These results suggest that employment quotas would have positively impacted in the ER of disabled persons, reducing the gaps in relation to the mildly disabled and nondisabled. In turn, the differences between the mildly disabled and nondisabled reduce only slightly ( 0.8 percentage point), mostly due to unobservable factors ( 0.6 percentage points).

Table 7: Decomposition of the differences in the ER

\begin{tabular}{l|rrr|rrr|rrr}
\hline Source of & \multicolumn{3}{|c|}{ Severely-Mildly } & \multicolumn{3}{c|}{ Severely-Nondisabled } & \multicolumn{2}{c}{ Mildly-Nondisabled } \\
\cline { 2 - 10 } Difference & $\mathbf{2 0 0 0}$ & $\mathbf{2 0 1 0}$ & $\mathbf{1 0 - 0 0}$ & $\mathbf{2 0 0 0}$ & $\mathbf{2 0 1 0}$ & $\mathbf{1 0 - 0 0}$ & $\mathbf{2 0 0 0}$ & $\mathbf{2 0 1 0}$ & $\mathbf{1 0 - 0 0}$ \\
\hline Characteristics & -1.6 & -3.5 & -1.9 & -5.2 & -6.7 & -1.5 & -3.5 & -3.3 & 0.2 \\
Education & -2.2 & -3.2 & -1.0 & -4.7 & -5.2 & -0.5 & -2.6 & -2.2 & 0.5 \\
Age & -0.9 & -0.8 & 0.1 & -0.2 & 0.5 & 0.7 & 1.0 & 1.3 & 0.4 \\
Gender & 1.5 & 0.7 & -0.9 & 0.1 & -1.2 & -1.3 & -1.3 & -1.8 & -0.5 \\
Race/Color & 0.0 & 0.0 & 0.0 & 0.1 & 0.0 & -0.1 & 0.0 & 0.0 & 0.0 \\
Federal Units & 0.0 & -0.1 & -0.2 & -0.4 & -0.8 & -0.4 & -0.7 & -0.8 & -0.1 \\
Coefficients & -19.3 & -13.7 & 5.6 & -21.8 & -15.8 & 6.0 & -2.5 & -2.0 & 0.6 \\
Total & -20.9 & -17.2 & 3.7 & -26.9 & -22.5 & 4.4 & -6.1 & -5.3 & 0.8 \\
\hline Source: Demographic Census, IBGE. \\
Working age population (15 to 65 years old). \\
Decomposition based on the OLS estimates for the LPM. Values multiplied by 100.
\end{tabular}

In 2010, the wage difference separating severely and mildly disabled workers $\left(e^{-0.2131}-1=19.2 \%\right)$ was twice as large as that separating the mildly disabled and nondisabled $\left(e^{-0.1021}-1=9.7 \%\right)$. Socioeconomic and occupational characteristics are relevant in explaining wage differences between disabled and nondisabled workers, but they are not the main determinants. The total difference of wages between severely and nondisabled workers was equal to $27 \%\left(e^{-0.315}-1\right)$, mainly due to unobservable factors $\left(e^{-0.205}-1=18.5 \%\right)$. In other words, only one third of the differences between severely disabled and nondisabled persons were due to the workers' characteristics, i.e., due to the fact that disabled workers were overrepresented in more vulnerable social groups. The other two thirds were due to different marginal returns of socioeconomic and occupational characteristics (effects of the coefficients). This result would, for example, be related to the fact that disabled workers have lower marginal returns of age on earnings. This effect of coefficients also represents the impact of variables not controlled in the analyses, such as social 
discrimination, occupational segregation, occupational skills, and other hidden factors affecting labor productivity.

Between 2000 and 2010, the average wage of nondisabled workers grew at a slow pace compared to other groups of disability. As a result, differences in relation to disabled and mildly disabled workers reduced considerably. For example, the difference between the mean log wages of the disabled and nondisabled decreased 7.6 points, from 39.1 points in 2000 to 31.5 in 2010 . Only 1.1 points of this reduction was due to the faster reduction in the marginal returns of socioeconomic and occupational characteristics for disabled workers (effect of coefficients). The largest share of this reduction, 6.5 points, was due to changes in the socioeconomic and occupational characteristics of people with disabilities (effect of characteristics), i.e. due to a faster decrease of occupational and socioeconomic vulnerabilities among the disabled in relation to nondisabled workers.

On the one hand, this result indicates that employment quotas had no substantial impact on wage discrimination against disabled persons, since unobservable differences reduced only slightly. Disabled workers continue to receive equally less than their nondisabled counterparts. On the other hand, it also suggests that only skilled workers with severe disabilities benefited from employment quotas, attaining high paying jobs, and hence, reducing differences due to observable characteristics.

Table 8: Decomposition of the differences in the mean log wage

\begin{tabular}{l|rrr|rrr|rrr}
\hline \multirow{2}{*}{$\begin{array}{l}\text { Source of } \\
\text { Difference }\end{array}$} & \multicolumn{3}{|c}{ Severely-Mildly } & \multicolumn{3}{c|}{ Severely-Nondisabled } & \multicolumn{3}{c}{ Mildly-Nondisabled } \\
\cline { 2 - 9 } & $\mathbf{2 0 0 0}$ & $\mathbf{2 0 1 0}$ & $\mathbf{1 0 - 0 0}$ & $\mathbf{2 0 0 0}$ & $\mathbf{2 0 1 0}$ & $\mathbf{1 0 - 0 0}$ & $\mathbf{2 0 0 0}$ & $\mathbf{2 0 1 0}$ & $\mathbf{1 0 - 0 0}$ \\
\hline Characteristics & -9.0 & -11.1 & -2.1 & -17.5 & -11.0 & 6.5 & -8.8 & -1.3 & 7.5 \\
Education & -5.1 & -6.9 & -1.9 & -16.0 & -11.9 & 4.0 & -11.2 & -5.7 & 5.5 \\
Age & -1.4 & 0.9 & 2.3 & 11.1 & 12.9 & 1.8 & 12.7 & 11.9 & -0.8 \\
Gender & 0.7 & 0.3 & -0.4 & 0.3 & -1.5 & -1.7 & -0.3 & -1.7 & -1.4 \\
Race/Color & 0.0 & -0.3 & -0.3 & -1.0 & -0.9 & 0.1 & -0.9 & -0.5 & 0.4 \\
Working Hour & -0.7 & -0.7 & -0.1 & -2.0 & -2.1 & 0.0 & -1.4 & -1.3 & 0.0 \\
Employment Status & -1.6 & -1.8 & -0.2 & -1.8 & -2.6 & -0.8 & -0.5 & -1.1 & -0.5 \\
Economic Sector & -1.3 & -1.8 & -0.5 & -3.8 & -2.6 & 1.1 & -2.5 & -1.0 & 1.5 \\
Federal Units & 0.4 & -0.7 & -1.1 & -4.2 & -2.4 & 1.8 & -4.6 & -1.8 & 2.9 \\
Coefficients & -10.2 & -10.2 & -0.1 & -21.6 & -20.5 & 1.1 & -11.1 & -8.9 & 2.2 \\
Total & -19.2 & -21.3 & -2.2 & -39.1 & -31.5 & 7.6 & -19.9 & -10.2 & 9.7 \\
\hline
\end{tabular}

Source: Demographic Census, IBGE.

Employed population with positive earnings.

Decomposition based on the OLS estimates for the LPM. Values multiplied by 100.

The reduction of the differences between the mildly disabled and nondisabled was more pronounced than that observed for severely disabled workers, also mainly due to the reduction in the differences of socioeconomic and occupational characteristics of these groups (effect of characteristics). In other words, the dynamics of average wages for people with less severe disabilities to some extent reproduced the behavior observed in people with more severe disabilities, even though the former group has benefited most in the period. As a result, differences between severely and mildly disabled persons increased 2 percentage points, mainly due to the effect of socioeconomic and occupational characteristics, i.e., mildly disabled workers attaining better positions. 


\subsection{Robustness Test of the Decomposition Procedure}

Table 9 now presents the decomposition accounting for sample selection bias. Estimates were based on Equation (12) and include a new source of variation: selectivity, which represents the unobservable differences between employed and non-employed persons. The main effect of accounting for selectivity in the otherwise standard decomposition (Equation 8) is that of increasing the discriminatory component (effect of coefficients) of the differences between the groups of disability.

The positive selectivity of severely disabled workers favors the average income of this group in relation to the groups of mildly disabled and nondisabled workers. In turn, the lower marginal returns of socio-occupational characteristics of the former group more than offset this positive impact on wages, explaining to a large extent the lower average wage of the severely disabled in relation to the mildly and nondisabled workers.

The role of selectivity on wage differences reduced remarkably between 2000 and 2010, especially among severely disabled workers. Since more severely disabled workers are attaining jobs in the labor market, this employed population is not as selective as it used to be. The contribution of selectivity to wage differences between the disabled and mildly disabled reduced by 104.6 points and by 94.4 points in the case of differences between severely disabled and nondisabled workers. In turn, this reduction was totally offset by increases in the discriminatory component (effect of coefficients).

\section{Final Discussion}

In $2010,6 \%$ of the WAP (8.2 million Brazilians) reported great or total difficulty in walking, hearing and/or seeing, or mental disabilities (disabled person). In turn, $17 \%$ of the WAP reported only a minor difficulty to perform such actions (25.1 millions of mildly disabled persons). Overall, 33.3 million people of working age - one quarter of the Brazilian WAP - present some level of disability and/or functional limitations. This prevalence is substantially larger than those of developed nations (roughly 14\%, according to OECD, 2013), which is probably related to the low levels of education, income, health assistance, and the preponderance of physically more demanding and hazardous occupations in Brazil.

Unsurprisingly, the group of people subjected to greater degrees of functional limitations faces less favorable conditions of work and earnings (see also, for example, Garcia \& Maia (2014)). Those mildly disabled persons are in an intermediate position, albeit with occupational attainment significantly those observed for the general population with no disabolities or functional limitations (nondisabled). Proportionally, disabled persons barely participate in the labor market, especially those with cognitive problems and with great physical disabilities. Only 39\% of the WAP with more severe disabilities were employed in 2010 (3.2 million people), compared to $57 \%$ of mildly disabled and $62 \%$ of nondisabled persons. The relative employment rates of the severely and mildly disabled over non-disabled people in Brazil (64\% and $91 \%$ in 2010, respectively) were also far larger than those observed in developed nations (roughly 33\% and 70\%, according to OCDE, 2013), which can be attributed to both mandatory employment quotas and the extent of the social 
Table 9: Decomposition of the differences in the mean log wage with sample selection correction

\begin{tabular}{l|rrr|rrr|rrr}
\hline Source of & \multicolumn{3}{|c|}{ Severely-Mildly } & \multicolumn{3}{c}{ Severely-Nondisabled } & \multicolumn{3}{c}{ Mildly-Nondisabled } \\
\cline { 2 - 10 } Difference & $\mathbf{2 0 0 0}$ & $\mathbf{2 0 1 0}$ & $\mathbf{1 0 - 0 0}$ & $\mathbf{2 0 0 0}$ & $\mathbf{2 0 1 0}$ & $\mathbf{1 0 - 0 0}$ & $\mathbf{2 0 0 0}$ & $\mathbf{2 0 1 0}$ & $\mathbf{1 0 - 0 0}$ \\
\hline Characteristics & -9.7 & -11.9 & -2.2 & -23.4 & -16.4 & 7.0 & -13.1 & -4.6 & 8.5 \\
Education & -5.7 & -7.6 & -1.9 & -20.4 & -15.2 & 5.2 & -14.4 & -7.4 & 7.0 \\
Age & -1.9 & 0.7 & 2.6 & 10.2 & 13.0 & 2.7 & 13.1 & 12.4 & -0.7 \\
Gender & 1.0 & 0.4 & -0.6 & 0.5 & -2.6 & -3.1 & -0.8 & -3.0 & -2.2 \\
Race/Color & 0.0 & -0.3 & -0.3 & -0.9 & -0.9 & 0.0 & -0.9 & -0.6 & 0.3 \\
Working Hour & -0.7 & -0.8 & -0.1 & -2.0 & -2.1 & -0.1 & -1.3 & -1.3 & 0.0 \\
Employment Status & -1.6 & -1.8 & -0.2 & -1.9 & -2.6 & -0.7 & -0.6 & -1.1 & -0.5 \\
Economic Sector & -1.3 & -1.8 & -0.5 & -3.8 & -2.7 & 1.1 & -2.5 & -1.0 & 1.4 \\
Federal Units & 0.4 & -0.7 & -1.2 & -5.1 & -3.4 & 1.7 & -5.8 & -2.6 & 3.2 \\
Coefficients & -149.5 & -44.9 & 104.6 & -127.8 & -32.8 & 95.0 & 21.2 & 12.2 & -9.0 \\
Selectivity & 140.1 & 35.5 & -104.6 & 112.0 & 17.6 & -94.4 & -28.1 & -17.9 & 10.2 \\
Total & -19.2 & -21.3 & -2.2 & -39.1 & -31.6 & 7.6 & -20.0 & -10.2 & 9.7 \\
\hline
\end{tabular}

Source: Demographic Census, IBGE.

Working age population (15 to 65 years old).

Decomposition based on the OLS estimates for the LPM. Values multiplied by 100. 
benefits for non-employed disabled persons: many people with disability in Brazil may have no other choice rather than to be employed to making a living.

To a large extent, the employment differences between disabled and nondisabled persons reflect the most unfavorable conditions that individuals with greater degrees of physical, sensory or cognitive limitations are subjected to in their search for jobs. In fact, part of this group would not be able to exert a productive activity given their more serious and vulnerable physical, sensory and/or cognitive limitations. Nonetheless, many people with disabilities are fully able to perform occupational activities and would be involuntarily inactive due to hidden difficulties that are not faced by other members, such as lack of appropriate infrastructure and social discrimination.

Many of these difficulties faced by disabled persons are unobservable factors, which represent the most significant share of the differences of employment rates in comparison with other groups of disability (mildly disabled and nondisabled): roughly $70 \%$ in 2010 . The contribution of unobservable factors on employment differences in Brazil is far beyond that observed in other studies, particularly in the United Kingdom (roughly 50\%, according to Jones (2008)). In Brazil, only a smaller share of the employment differences can therefore be explained by socioeconomic differences between these groups, i.e., due to the fact that disabled persons present more vulnerable characteristics, such as being older and having lower education. Less severe are the difficulties faced by mildly disabled persons. The employment rate of these people is slightly lower than that of the nondisabled, and this difference is mainly due to the socioeconomic characteristics of the groups. In order words, this latter group would not be facing harder difficulties to find a job when compared to the nondisabled group.

Differences between the employment rates of the groups of disability reduced significantly between 2000 and 2010: 4 percentage points between disabled and both nondisabled and mildly disabled persons. More importantly, these reductions were almost exclusively due to unobservable factors. This period corresponds to the enforcement of the employment quotas, the Brazilian Federal Law that reserves a share of jobs in private and public companies for people with disabilities, which may probably have impacted social discrimination and other unobservable constraints faced by people with disabilities. Moreover, contrary to what would be expected, the growth in the ER of disabled persons did not happen at the expense of other social groups, since the ER grew for most social groups.

In addition to lower labor force participation rates, disabled persons are also overrepresented in the most vulnerable socioeconomic groups and subjected to the worst conditions of earnings and employment. Naturally, the discrepancy is more apparent when the comparison is made between disabled and nondisabled workers: an average wage that is $27 \%$ lower for the former group in 2010. Socioeconomic and occupational characteristics explain just a small share of this gap. The most representative share is due to unobservable factors (roughly two thirds). The contribution of unobservable factors on wage gaps is also far beyond that observed in developed nations (for example, Malo \& Pagán (2012)), which can be partially explained by the lower levels of inequality and more developed policies of social protection in the latter countries.

A major problem in the wage decomposition is caused by the selectivity 
bias. The groups of employed individuals have shown themselves not to be mere random selected samples of the WAP. The selection bias caused by the incidental selection of the employed population was positive and larger for the groups of severely disabled. Probably because severely disabled workers with lack of special skills will hardly find a job. As a result, the selection bias in the wage equation tends to reduce real differences between severely disabled and nondisabled (or mildly disabled) waged workers. Nonetheless, selectivity among severely disabled reduced remarkably after the implementation of employment quotas. In other words, the labor market for severely disabled workers became more inclusive.

Overall, results suggest that employment quotas in Brazil has a positive impact, increasing both the employment rate and average wage of disabled persons. The policy seems to have favored people with more severe levels of limitations mainly in their access to employment. The employment rate of this group increased faster than other groups, mainly due to lower effects of unobservable factors. In turn, people with less severe functional limitations were especially benefited in the distribution of earnings since their average wages increased faster than others. In this case, observable factors were the main responsible factors for reducing the wage gap. In other words, although the employment rate of disabled laborers increased faster after the enforcement of employment quotas, the best paying occupational positions would be attained by mildly disabled and more qualified workers. Nonetheless, unobservable differences, which include discrimination and other hidden difficulties affecting employment and wages, remain as a main source of inequality between these groups.

\section{Conclusions and Limitations}

Results in this study do not necessarily imply a causal relation between employment quotas and the patterns of employment and earnings in the labor market. In other words, it cannot be stated that employment quotas have been solely responsible for the changes observed in the period of analysis. Brazil benefited from extremely favorable economic conditions in the 2000s, when employment rates and wages soared for most social groups. Important institutional changes occurred in this period, which may also have affected the groups of disability in different ways. One can highlight, for example, the relevant increases in the minimum wage, which have mainly benefited the wages of low-skilled workers.

A more accurate analysis would undoubtedly be provided by a panel of beneficiaries and non-beneficiaries, after and before the implementation of employment quotas. Unfortunately, this information is not easily available. Nevertheless, the Demographic Census provides the largest and richest source of information to analyze the socioeconomic conditions of people with disabilities. The Census introduced self-reported questions about the individual's degree of disability in 2000 and 2010, a period in which employment quotas were effectively enforced in Brazil. The definition of disability used in the Census differs to some extent from the official criterion of employment quotas, which is based on a medical report. But several categories of disability are provided in the Census, allowing a precise analysis of employment conditions 
for people with different levels and types of disabilities. It is particularly important to understand how the group with more severe disabilities, which is subjected to worst employment conditions and highest levels of discrimination, may have benefited from employment quotas.

The results based on the Census data provide evidences that employment quotas may have positively affected the labor market for people with disabilities. First, because changes were more pronounced in the employment rates of people with more severe disabilities, the main group benefited by employment quotas. Second, because the reduction in the employment gap between disabled and non-disabled people was almost exclusively due to unobservable factors, suggesting lower hiring discrimination. Third, since employment quotas do not guarantee better wages for people with disabilities, the decrease in wage inequality between disabled and non-disabled workers was mainly due to non-institutional factors, more specifically, better skills in the group of severely disabled workers.

Some limitations of these analyses must also be highlighted. First, the lack of more accurate measures for productive factors that also affect earnings (professional qualifications and skills, for example) can inflate the unexplained component in the strategy of decomposition. However, unobserved factors can also represent the level of physical, sensory and cognitive limitations, limiting the access to jobs and the employment stability of disabled persons. As a result, the marginal returns on earnings for some socioeconomic characteristics are lower among people with disabilities, especially the marginal returns of age. Unobserved factors can also reflect employers' discrimination against people with disabilities: sharing the same professional skills as their peers, they would face extra difficulties to further their career.

Finally, the results presented in this study provide some important elements to discuss the effectiveness of public policies aimed at people with disabilities. The employment quotas in Brazil have shown to be more successful than antidiscrimination laws observed in developed countries. This successful experience was only guaranteed by strict and continuous federal inspection in private and public companies. Nonetheless, the persistence of substantial gaps between the groups of disability reinforces the idea that reserving jobs in the market will be unable, per se, to equalize the inequality of opportunities faced by this social group. Education and work experience are central determinants in the access to well paid jobs and must be promoted, for example, through skill training programs for people with disabilities. But improving education, working hours and occupational attainment of people with disabilities will not be enough to eliminate pay inequalities between the groups of disability. Differences that are not related to socioeconomic and occupational characteristics could be attenuated by strengthening the concept of accessibility in public and private spaces. This involves the removal of barriers in the access to education, health, transport, and other public and private services that hamper the employment opportunities of people with disabilities. Finally, these policies will not be successful without increasing awareness among employers to eliminate the negative stereotypes that are still associated with disabled persons. 


\section{References}

Acemoglu, D. \& Angrist, J. (1998), Consequences of employment protection? The case of the Americans with disabilities act, Working Paper 6670, National Bureau of Economic Research.

Baldwin, M. L. \& Choe, C. (2014), 'Re-examining the models used to estimate disability-related wage discrimination', Applied Economics 46(12), 13931408.

URL: $h$ ttps://doi.org/10.1080/00036846.2013.872762

Beegle, K. \& Stock, W. A. (2003), 'The labor market effects of disability discrimination laws', Journal of Human Resources 38(4), 806-859.

URL: https://ideas.repec.org/a/uwp/jhriss/v38y2003i4p806-859.html

Blinder, A. S. (1973), 'Wage discrimination: reduced form and structural estimates', The Journal of Human Resources 8(4), 436-455.

URL: $h t t p: / / w w w . j s t o r . o r g / s t a b l e / 144855$

Cameron, C. A. \& Trivedi, P. (2005), Microeconometrics: methods and applications.

Costilla, H. G., Neri, M. \& Carvalho, A. (2002), Política de cotas e inclusão trabalhista das pessoas com deficiência, Ensaios Economicos da EPGE 462, EPGE/FGV.

Deleire, T. (2000), 'The wage and employment effects of the Americans with disabilities act', Journal of Human Resources 35, 693-715.

Deleire, T. (2001), 'Changes in wage discrimination against people with disabilities: 1984-93', Journal of Human Resources 36, 144-158.

Figueira, E. (2009), Caminhando em silêncio: uma introdução à trajetória das pessoas com deficiência na história do Brasil, Giz.

Frutos, E. M. L. \& Castello, J. V. (2015), 'Equal health, equal work? The role of disability benefits in employment after controlling for health status', The European Journal Of Health Economics, HEPAC: Health Economics In Prevention And Care 16(3), 329-340.

Garcia, V. G. (2010), Pessoas com deficiência e o mercado de trabalho: histórico e contexto contemporâneo, $\mathrm{PhD}$ thesis, Instituto de Economia, Universidade Estadual de Campinas.

Garcia, V. G. \& Maia, A. G. (2014), 'Características da participação das pessoas com deficiência e/ou limitação funcional no mercado de trabalho brasileiro', Revista Brasileira de Estudos de População (2), 395.

Griffin, P. (1992), 'The impact of affirmative action on labor demand: a test of some implications of the Le Chatelier principle', The Review of Economics and Statistics 74(2), 251-260.

Halvorsen, R. \& Palmquist, R. (1980), 'The interpretation of dummy variables in semilogarithmic equations', American Economic Review 70(3), 474-475. 
Hasegawa, T. (2007), 'Equality of opportunity or employment quotas? A comparison of Japanese and American employment policies for the disabled', Social Science Japan Journal 10, 41-57.

Haveman, R. \& Wolfe, B. (1990), 'The economic well-being of the disabled: 1962-84', Journal of Human Resources 25(1), 32-54.

Heckman, J. J. (1976), The common structure of statistical models of truncation, sample selection and limited dependent variables and a simple estimator for such models, in 'Annals of Economic and Social Measurement, Volume 5, number 4', NBER Chapters, National Bureau of Economic Research, Inc, pp. 475-492.

Hoffmann, R. (2000), Mensuração da desigualdade e da pobreza no Brasil, in R. Henriques, ed., 'Desigualdade e Pobreza no Brasil', IPEA, Rio de Janeiro, pp. 81-107.

Hotchkiss, J. L. (2004), 'A closer look at the employment impact of the Americans with disabilities act', Journal of Human Resources 39(4), 887-911.

Jones, M. (2008), 'Disability and the labour market: a review of the empirical evidence', Journal of Economic Studies 35, 405-424.

Jones, M. K. (2006), 'Is there employment discrimination against the disabled?', Economics Letters 92(1), 32-37.

Kidd, M. P., Sloane, P. J. \& Ferko, I. (2000), 'Disability and the labour market: an analysis of British males', Journal of Health Economics 19(6), 961-981.

Kruse, D. \& Schur, L. (2003), 'Employment of people with disabilities the ADA', Industrial Relations: A Journal of Economy and Society 42(1), 31-66.

Madden, D. (2004), 'Labour market discrimination on the basis of health: an application to UK data', Applied Economics 36, 421-442.

Malo, M. Á. \& Pagán, R. (2012), 'Wage differentials and disability across Europe: discrimination and/or lower productivity?', International Labour Review 151(1-2), 43-60.

Marchon, C. \& Toledo, H. (2014), 'Re-thinking employment quotas in the UAE', The International Journal of Human Resource Management 25(16), 22532274.

Maroto, M. \& Pettinicchio, D. (2014), 'Disability, structural inequality, and work: the influence of occupational segregation on earnings for people with different disabilities', Research in Social Stratification and Mobility 38, 76-92. URL: $h t t p: / / w w w . s c i e n c e d i r e c t . c o m / s c i e n c e / a r t i c l e / p i i / S 0276562414000560$

McNeil, J. (2000), Employment, earnings, and disability, U.S. Bureau of the Census, Washington.

Nazarov, Z., Kang, D. \& Von Schrader, S. (2015), 'Employment quota system and labour market outcomes of individuals with disabilities: empirical evidence from South Korea', Fiscal Studies 36(1), 99-126. 
Neuman, S. \& Oaxaca, R. (2004a), 'Wage decompositions with selectivitycorrected wage equations: a methodological note', Journal of Economic Inequality 2, 3-10.

Neuman, S. \& Oaxaca, R. (2004b), 'Wage differentials in the 1990s in Israel: endowments, discrimination, and selectivity', International Journal of Manpower 26.

Oaxaca, R. (1973), 'Male-female wage differentials in urban labor markets', International Economic Review 14(3), 693.

OECD (2003), Transforming disability into ability.

Olson, W. (1997), The excuse factory: how employment law is paralyzing the American workplace, Free Press, New York.

Ravaud, J. F., Madiot, B. \& Ville, I. D. S. (1992), 'Discrimination towards disabled people seeking employment', Social Science E Medicine 35(8), 951958.

Sassaki, R. K. (2008), Artigo 19: a convenção sobre direitos das pessoas com deficiência comentada, Secretaria Especial dos Direitos Humanos, Coordenadoria Nacional para Integração da Pessoa Portadora de Deficiência, Brasília.

Silva, O. M. (1987), A epopeia ignorada: a pessoa deficiente na historia do mundo de ontem e de hoje, CEDAS.

URL: $\quad h t t p: / / s e a r c h . e b s c o h o s t . c o m / l o g i n . a s p x ?$ direct $=$ true $\delta d b=$ cat04198aE A $N=$ unicamp.000116803Elang $=p t$-brEsite $=$ eds-liveEscope $=$ site

Vaz, D. V. \& Hoffmann, R. (2007), 'Remuneração nos serviços no Brasil: o contraste entre funcionários públicos e privados', Economia e Sociedade (2), 199232.

Webber, D. A. \& Bjelland, M. J. (2015), 'The impact of work-limiting disability on labor force participation', Health Economics 24(3), 333-352.

Welch, F. (1976), 'Employment quotas for minorities', Journal of Political Economy 84, 105-39.

Wooldridge, J. (2002), Introductory econometrics: a modern approach, Vol. 2th edition, Thomson, South-Western.

Wüllrich, J.-P. (2010), 'The effects of increasing financial incentives for firms to promote employment of disabled workers', Economics Letters 107, 173176.

Yelin, E. H. \& Katz, P. P. (1994), 'Labor force trends of persons with and without disabilities', Monthly Labor Review 117(10), 36-42.

Zanitelli, L. M. (2013), 'A lei de cotas para pessoas portadoras de deficiência nas empresas brasileiras: impacto e possíveis alternativas', Ciência E Saúde Coletiva (7), 2085.

\section{Appendix A}


Table A.1: Explanatory variables of the models for log wage and ER

\begin{tabular}{|c|c|c|}
\hline Variable & & Description \\
\hline $\begin{array}{l}\text { Education } \\
\text { (with } \\
\text { or without } \\
\text { diploma) }\end{array}$ & $\begin{array}{l}\text { No Education } \\
\text { Elementary } \\
\text { Middle } \\
\text { College }\end{array}$ & $\begin{array}{l}\text { reference } \\
1 \text { if elementary education; } 0 \text { otherwise } \\
1 \text { if secondary education; } 0 \text { otherwise } \\
1 \text { if tertiary education; } 0 \text { otherwise } \\
\end{array}$ \\
\hline Age & $\begin{array}{l}15 \text { to } 19 \\
20 \text { to } 29 \\
30 \text { to } 39 \\
40 \text { to } 49 \\
50 \text { to } 59 \\
60 \text { to } 65 \\
\end{array}$ & $\begin{array}{l}\text { reference } \\
1 \text { if between } 20 \text { and } 29 \text { years old; } 0 \text { otherwise } \\
1 \text { if between } 30 \text { and } 39 \text { years old; } 0 \text { otherwise } \\
1 \text { if between } 40 \text { and } 49 \text { years old; } 0 \text { otherwise } \\
1 \text { if between } 50 \text { and } 59 \text { years old; } 0 \text { otherwise } \\
1 \text { if between } 60 \text { and } 65 \text { years old; } 0 \text { otherwise }\end{array}$ \\
\hline Gender & Female & 1 if female; 0 if male \\
\hline Race/Color & $\begin{array}{l}\text { White } \\
\text { Black } \\
\text { Yellow } \\
\text { Brown } \\
\text { Indigenous } \\
\end{array}$ & $\begin{array}{l}\text { reference } \\
1 \text { if black; } 0 \text { otherwise } \\
1 \text { if yellow; } 0 \text { otherwise } \\
1 \text { if brown; } 0 \text { otherwise } \\
1 \text { if indigenous; } 0 \text { otherwise }\end{array}$ \\
\hline Working Hour & $\begin{array}{l}20 \mathrm{~h} \text { or Less } \\
21 \text { to } 39 \mathrm{~h} \\
40 \text { to } 44 \mathrm{~h} \\
45 \mathrm{~h} \text { or More }\end{array}$ & $\begin{array}{l}\text { reference } \\
1 \text { if between } 21 \text { and } 39 \text { hours per week; } 0 \text { otherwise } \\
1 \text { if between } 40 \text { and } 44 \text { hours per week; } 0 \text { otherwise } \\
1 \text { if } 45 \text { hours per week or more; } 0 \text { otherwise }\end{array}$ \\
\hline
\end{tabular}


Table A.1: Explanatory variables of the models for log wage and ER (continuation)

\begin{tabular}{|c|c|c|}
\hline Variable & & Description \\
\hline $\begin{array}{l}\text { Employment } \\
\text { Status }\end{array}$ & $\begin{array}{l}\text { Formal Employee } \\
\text { Civil Servant } \\
\text { Informal Employee } \\
\text { Self-employed } \\
\text { Employer } \\
\end{array}$ & $\begin{array}{l}\text { reference } \\
1 \text { if civil cervant; } 0 \text { otherwise } \\
1 \text { if informal employee; } 0 \text { otherwise } \\
1 \text { if self-employed; } 0 \text { oherwise } \\
1 \text { if employer; } 0 \text { otherwise }\end{array}$ \\
\hline $\begin{array}{l}\text { Economic } \\
\text { Sector }\end{array}$ & $\begin{array}{l}\text { Agriculture } \\
\text { Manufacturing } \\
\text { Other Industrial Activities } \\
\text { Construction } \\
\text { Trade and Repair } \\
\text { Accomodation and Food } \\
\text { Transp., wareh., communic. } \\
\text { Public Administration } \\
\text { Education, Health and Social } \\
\text { Other Social and Personal } \\
\text { Domestic Service } \\
\text { Other Activities }\end{array}$ & $\begin{array}{l}\text { reference } \\
1 \text { if work in manufacturing; } 0 \text { otherwise } \\
1 \text { if work in other industrial activities; } 0 \text { otherwise } \\
1 \text { if work in construction; } 0 \text { otherwise } \\
1 \text { if work in trade or repair and maintenance; } 0 \text { otherwise } \\
1 \text { if work in accommodation or food service; } 0 \text { otherwise } \\
1 \text { if work in tranportation, warehousing and telecommunnication; } 0 \text { otherwise } \\
1 \text { if work in public administration; } 0 \text { otherwise } \\
1 \text { if work in education, health and social services; } 0 \text { otherwise } \\
1 \text { if work in other social and personal services; } 0 \text { otherwise } \\
1 \text { if work in domestic services; } 0 \text { otherwise } \\
1 \text { if work in other activities; } 0 \text { otherwise; }\end{array}$ \\
\hline Fixed Effects & 27 Federal Units & \\
\hline
\end{tabular}


Table A.2: Maximum likelihood estimates of the probit model having the binary dependent variable employed, according to group of disability. Working age population, Brazil 2000 and 2010

\begin{tabular}{|c|c|c|c|c|c|c|}
\hline \multirow[b]{2}{*}{ Variable } & \multicolumn{3}{|c|}{2000} & \multicolumn{3}{|c|}{2010} \\
\hline & $\begin{array}{l}\text { Severely } \\
\text { Disabled }\end{array}$ & $\begin{array}{c}\text { Mildly } \\
\text { Disabled }\end{array}$ & $\begin{array}{c}\text { Non- } \\
\text { disabled }\end{array}$ & $\begin{array}{l}\text { Severely } \\
\text { Disabled }\end{array}$ & $\begin{array}{c}\text { Mildly } \\
\text { Disabled }\end{array}$ & $\begin{array}{c}\text { Non- } \\
\text { disabled }\end{array}$ \\
\hline Intercept & $\begin{array}{c}-1.436 \\
(0.010)\end{array}$ & $\begin{array}{c}-0.472 \\
(0.006)\end{array}$ & $\begin{array}{c}-0.485 \\
(0.004)\end{array}$ & $\begin{array}{c}-1.453 \\
(0.009)\end{array}$ & $\begin{array}{c}-0.660 \\
(0.005)\end{array}$ & $\begin{array}{c}-0.713 \\
(0.005)\end{array}$ \\
\hline Elementary & $\begin{array}{c}0.511 \\
(0.005)\end{array}$ & $\begin{array}{c}0.212 \\
(0.003)\end{array}$ & $\begin{array}{c}0.229 \\
(0.003)\end{array}$ & $\begin{array}{c}0.597 \\
(0.004)\end{array}$ & $\begin{array}{c}0.306 \\
(0.003)\end{array}$ & $\begin{array}{c}0.359 \\
(0.004)\end{array}$ \\
\hline Middle & $\begin{array}{c}0.955 \\
(0.007)\end{array}$ & $\begin{array}{c}0.541 \\
(0.004)\end{array}$ & $\begin{array}{c}0.508 \\
(0.003)\end{array}$ & $\begin{array}{c}1.015 \\
(0.005)\end{array}$ & $\begin{array}{c}0.617 \\
(0.004)\end{array}$ & $\begin{array}{c}0.650 \\
(0.004)\end{array}$ \\
\hline College & $\begin{array}{c}1.340 \\
(0.011)\end{array}$ & $\begin{array}{c}0.904 \\
(0.006)\end{array}$ & $\begin{array}{c}0.823 \\
(0.004) \\
\end{array}$ & $\begin{array}{c}1.455 \\
(0.007) \\
\end{array}$ & $\begin{array}{c}0.980 \\
(0.004)\end{array}$ & $\begin{array}{c}0.956 \\
(0.004) \\
\end{array}$ \\
\hline 20 to 29 & $\begin{array}{c}0.512 \\
(0.009)\end{array}$ & $\begin{array}{c}0.785 \\
(0.005)\end{array}$ & $\begin{array}{c}0.876 \\
(0.002)\end{array}$ & $\begin{array}{c}0.734 \\
(0.008)\end{array}$ & $\begin{array}{c}0.947 \\
(0.004)\end{array}$ & $\begin{array}{c}0.995 \\
(0.002)\end{array}$ \\
\hline 30 to 39 & $\begin{array}{c}0.673 \\
(0.009)\end{array}$ & $\begin{array}{c}0.991 \\
(0.005)\end{array}$ & $\begin{array}{c}1.148 \\
(0.002)\end{array}$ & $\begin{array}{c}0.964 \\
(0.008)\end{array}$ & $\begin{array}{c}1.225 \\
(0.004)\end{array}$ & $\begin{array}{c}1.321 \\
(0.003)\end{array}$ \\
\hline 40 to 49 & $\begin{array}{c}0.764 \\
(0.009)\end{array}$ & $\begin{array}{c}0.924 \\
(0.005)\end{array}$ & $\begin{array}{c}1.106 \\
(0.003)\end{array}$ & $\begin{array}{c}1.050 \\
(0.007)\end{array}$ & $\begin{array}{c}1.207 \\
(0.004)\end{array}$ & $\begin{array}{c}1.326 \\
(0.003)\end{array}$ \\
\hline 50 to 59 & $\begin{array}{c}0.599 \\
(0.009) \\
\end{array}$ & $\begin{array}{c}0.585 \\
(0.005) \\
\end{array}$ & $\begin{array}{c}0.726 \\
(0.003) \\
\end{array}$ & $\begin{array}{c}0.865 \\
(0.007) \\
\end{array}$ & $\begin{array}{c}0.882 \\
(0.004) \\
\end{array}$ & $\begin{array}{c}0.985 \\
(0.003) \\
\end{array}$ \\
\hline 60 to 65 & $\begin{array}{c}0.208 \\
(0.010)\end{array}$ & $\begin{array}{c}0.076 \\
(0.006)\end{array}$ & $\begin{array}{c}0.222 \\
(0.005)\end{array}$ & $\begin{array}{c}0.425 \\
(0.008)\end{array}$ & $\begin{array}{c}0.319 \\
(0.004)\end{array}$ & $\begin{array}{c}0.415 \\
(0.005)\end{array}$ \\
\hline Female & $\begin{array}{c}-0.514 \\
(0.004)\end{array}$ & $\begin{array}{c}-0.909 \\
(0.002)\end{array}$ & $\begin{array}{c}-0.868 \\
(0.002)\end{array}$ & $\begin{array}{c}-0.451 \\
(0.003)\end{array}$ & $\begin{array}{c}-0.731 \\
(0.002)\end{array}$ & $\begin{array}{c}-0.700 \\
(0.002)\end{array}$ \\
\hline$\overline{\text { Black }}$ & $\begin{array}{c}0.106 \\
(0.007) \\
\end{array}$ & $\begin{array}{c}0.065 \\
(0.004) \\
\end{array}$ & $\begin{array}{c}0.070 \\
(0.003) \\
\end{array}$ & $\begin{array}{c}0.120 \\
(0.005) \\
\end{array}$ & $\begin{array}{c}0.086 \\
(0.003) \\
\end{array}$ & $\begin{array}{c}0.063 \\
(0.003) \\
\end{array}$ \\
\hline Yellow & $\begin{array}{c}-0.108 \\
(0.033) \\
\end{array}$ & $\begin{array}{c}-0.050 \\
(0.017) \\
\end{array}$ & $\begin{array}{c}-0.155 \\
(0.011) \\
\end{array}$ & $\begin{array}{c}0.074 \\
(0.013) \\
\end{array}$ & $\begin{array}{c}-0.017 \\
(0.008) \\
\end{array}$ & $\begin{array}{c}-0.035 \\
(0.007) \\
\end{array}$ \\
\hline Brown & $\begin{array}{c}0.051 \\
(0.004)\end{array}$ & $\begin{array}{c}0.010 \\
(0.002)\end{array}$ & $\begin{array}{c}0.012 \\
(0.002)\end{array}$ & $\begin{array}{c}0.026 \\
(0.003)\end{array}$ & $\begin{array}{c}-0.005 \\
(0.002)\end{array}$ & $\begin{array}{c}-0.021 \\
(0.002)\end{array}$ \\
\hline Indigenous & $\begin{array}{c}0.112 \\
(0.026)\end{array}$ & $\begin{array}{c}-0.066 \\
(0.015)\end{array}$ & $\begin{array}{c}-0.219 \\
(0.012)\end{array}$ & $\begin{array}{c}0.036 \\
(0.022)\end{array}$ & $\begin{array}{c}-0.157 \\
(0.014)\end{array}$ & $\begin{array}{c}-0.401 \\
(0.013)\end{array}$ \\
\hline Federal Units & yes & yes & yes & yes & yes & yes \\
\hline Sample size & 520,597 & $1,534,326$ & $3,257,623$ & 904,451 & $2,644,458$ & $3,144,065$ \\
\hline Log likelihood|- & $-280,143$ & $-905,856$ & $-1,881,730$ & $-541,626$ & $-1,559,584$ & $-1,746,587$ \\
\hline
\end{tabular}

